\title{
A autonomia da pulsão de morte na metapsicologia freudiana
}

\author{
The autonomy of the death drive in Freudian metapsychology
}

\section{Fabio Caprio Leite de Castro*}

Resumo: Em Além do Princípio do Prazer, Freud propõe uma especulação sobre a pulsão de morte, mas percebe desde logo a dificuldade de isolá-la da pulsão de vida. A pulsão de morte possui autonomia em relação à pulsão de vida no quadro da teoria pulsional freudiana? Para responder essa questão, delimitando-a à psicanálise freudiana, propõe-se uma abordagem em quatro etapas. Em um primeiro ponto, faz-se um exercício hermenêutico baseado no texto Além do Princípio do Prazer. Logo depois, em um segundo ponto, amplia-se o exercício a outros textos de Freud que abordam e exemplificam a pulsão de morte. Em um terceiro ponto, coloca-se em foco o desenvolvimento teórico que levou Freud a afirmar a autonomia da pulsão de morte. Como Freud não oferece, mesmo em seus últimos textos, um exemplo claro da pulsão de morte isolada, apresentamos duas respostas possíveis, com base nas interpretações de Luiz Garcia-Roza e de Ignácio Paim Filho.

Palavras-chave: Psicanálise; Princípio do Prazer; Compulsão; Pulsão de Morte; Autonomia

Abstract: In Beyond the Pleasure Principle, Freud proposes a speculation about the death drive, but soon realizes the difficulty of isolating it from the life drive. Does the death drive have autonomy in relation to the life drive in the framework of the Freudian drive theory? To answer this question, delimited to the Freudian psychoanalysis, it is proposed an approach in four stages. In a first point, it is done a hermeneutic exercise based on the text Beyond the Pleasure Principle. Soon after, in a second point, the exercise is extended to other texts of Freud that approach and exemplify the drive of death. In a third point, the theoretical development that led Freud to assert the autonomy of the death drive is put in focus. As Freud does not offer, even in his last texts, a clear example of the isolated death drive, we present two possible answers, based on the interpretations of Luiz Garcia-Roza and Ignácio Paim Filho.

Keywords: Psychoanalysis; Pleasure Principle; Compulsion; Death Drive; Autonomy

\section{Introdução}

Em seu famoso livro Além do Princípio do Prazer, publicado em 1920, Freud apresenta o resultado de seus esforços especulativos para compreender e explicar o fenômeno da compulsão à repetição. Através de exemplos de fenômenos compulsivos - as neuroses de guerra, o jogo infantil e a repetição nas neuroses de transferência - Freud 
procura mostrar que eles contrariam, ou colocam em suspenso, a dominância do princípio do prazer. Haveria de existir outro princípio, mais original e mais poderoso que o princípio do prazer, capaz de suspendê-lo em certas ocasiões. Este mais além do princípio do prazer, que se expressa na compulsão à repetição, conduz Freud à hipótese da pulsão de morte - a qual se volta para retorno ao grau zero de tensão da vida orgânica, ou seja, o retorno ao inorgânico.

Entretanto, Freud percebe muito cedo que não era possível isolar a pulsão de morte nos exemplos de compulsão a repetição apresentados, assim como no caso do sadismo, no qual a expressão da pulsão de morte vem mesclada com algum conteúdo libidinal. Ora, não fosse possível isolar a pulsão de morte, persistiria o risco de a teoria psicanalítica das pulsões sucumbir diante da teoria do monismo pulsional, por exemplo, tal como esta foi defendida por Carl Jung. Não se tratava de um tema qualquer para Freud, mas de uma indagação que ele não cessou de fazer ao longo de sua obra. Com base nesse problema é estabelecida a questão a ser investigada nesse artigo: a pulsão de morte possui autonomia em relação à pulsão de vida no quadro da teoria pulsional freudiana?

Para dar uma resposta satisfatória à interrogação que propomos, é necessário percorrer as etapas da explicação sobre a pulsão de morte na teoria do dualismo pulsional em Freud. Em um primeiro ponto, propomos um exercício hermenêutico baseado no texto Além do Princípio do Prazer. Tomamos este livro como nosso ponto de partida, pois é nele que Freud apresenta a formulação do dualismo pulsional a partir dos conceitos de pulsão de vida e pulsão de morte. A análise deste livro nos permite interpretar, em um segundo ponto, outros textos de Freud que abordam e exemplificam a pulsão de morte. Em um terceiro ponto, examinamos o desenvolvimento teórico que levou Freud a afirmar a autonomia da pulsão de morte, com base na interpretação dos textos O eu o isso (1923), Mal-estar na cultura (1930) e na Conferência 32 - Angústia e vida pulsional (1933).

Permanece, entretanto, o problema. Além das inúmeras hesitações textuais de Freud em torno da sua teoria da pulsão de morte, jamais abandonadas, não há um exemplo sequer desta disposição pulsional autônoma em Mal-estar na cultura e na Conferência 32. Temos aqui um impasse hermenêutico. Afinal de contas, há ou não há uma autonomia da pulsão de morte? Em um quarto e último ponto, apresentamos duas respostas possíveis, com base nas interpretações de Luiz Alfredo Garcia-Roza e de Ignácio Paim Filho. Ambos afirmam a autonomia da pulsão de morte. Entretanto, Garcia-Roza ${ }^{1}$ o faz com o preço de inverter a teoria freudiana - ao afirmar que é a pulsão de morte que impede a repetição do mesmo -, enquanto Paim Filho ${ }^{2}$ mantém-se rigorosamente próximo ao texto de Freud e oferece uma resposta que nos parece mais satisfatória caso optemos uma hermenêutica restrita à psicanálise freudiana - a angústia é o exemplo mais genuíno da pulsão de morte

\footnotetext{
${ }^{1}$ ROZA, Introdução à Metapsicologia Freudiana. Volume 3

${ }^{2}$ PAIM FILHO, Metapsicologia
} 
desgarrada. Ao final, trataremos ainda das consequências dessa interpretação para a psicanálise.

\section{A pulsão de morte em Além do princípio do prazer}

O primeiro propósito deste ponto consiste em efetuar uma hermenêutica do texto de Freud, Além do princípio do prazer, publicado pela primeira vez em 1920 na Internationaler Psychoanalytischer Verlag. ${ }^{3}$. De uma justa interpretação deste texto dependerão todas as apreciações posteriores sobre a autonomia da pulsão de morte ${ }^{4}$.

A hermenêutica que propomos segue a ordem de exposição e de argumentação do próprio texto freudiano com seus sete itens. Faremos uma análise do texto em três partes, preservando as intenções pedagógicas da exposição freudiana. Inicialmente, propomos uma releitura do primeiro capítulo do texto, que oferece uma introdução ao tema sob a ótica do princípio de prazer como tendência à estabilidade. Em seguida, retomamos a descrição dos exemplos trazidos por Freud sob a categoria de compulsão a repetição. Por fim, ingressamos na tentativa feita por Freud de oferecer uma resposta à questão através de uma teorização sobre a pulsão de morte.

\subsection{A tendência à estabilidade como fundamento do princípio de prazer}

No primeiro ponto de Além do princípio do prazer, Freud realiza um gesto teórico que ratifica a herança advinda da psicofisiologia alemã do século XIX e, ao mesmo tempo, torna possível os desenvolvimentos especulativos subsequentes. Nosso objetivo será examinar o papel que o princípio de prazer, amparado pelo princípio da tendência à estabilidade de Fechner, possui na teoria psicanalítica freudiana.

A partir de sua formação médica (entre 1873 e 1881), podemos conjecturar com boas razões que Freud teve contato, por exemplo, com a teoria do recalcamento (Verdrängung)

\footnotetext{
${ }^{3}$ A citação dos textos freudianos foi feita com base na tradução argentina das obras completas (Amorrortu editores), abreviação “ $A E$ ”, ao lado da sua versão alemã original em sua edição de estudo (Studiensausgabe), abreviação " $S A$ ". A tradução do texto para o português, nas citações diretas, é livre e de nossa responsabilidade.

${ }^{4} \mathrm{O}$ uso do termo "autonomia" merece um esclarecimento. É Freud quem o utiliza no Mal-estar na Cultura, em 1930. Nesse texto, a inclinação agressiva é afirmada como uma disposição pulsional autônoma e originária do ser humano. (1930, $A E$, p. 117; $S A$, p. 249). Até esse texto, Freud não havia ainda afirmado o caráter autônomo da pulsão de morte de modo expresso, embora, como veremos, a sua preocupação em investigar essa característica remonte a Além do princípio do prazer. O adjetivo utilizado por Freud em alemão nessa passagem é selbständige, que pode ser traduzido por autônoma ou independente. Optamos por "autônoma", pois se Freud tivesse a intenção de dizer "independente", teria utilizado em alemão provavelmente o termo "unabhängige". A questão, nesse contexto, é a autonomia da pulsão de morte em relação à pulsão de vida.
} 
advinda da psicologia de Johann Friedrich Herbart ${ }^{5}$, assim como com a teoria da conservação da energia de Hermann Helmholtz e, por certo, com o mapeamento topográfico das redes neuronais proposto por Theodor Hermann Meyner, seu professor em Viena. No entanto, o autor que termina por ser decisivo na construção da psicanálise é o matemático e físico Gustav Theodor Fechner, defensor da correspondência entre as dimensões psíquica e fisiológica ${ }^{6}$.

Fechner tornou-se famoso especialmente pela formulação do princípio da tendência à estabilidade (Tendenz zur Stabilität). No primeiro volume dos Elementos da Psicofísica, de 1860, ele sustentou que a magnitude da força viva existente e potencial é uma quantidade constante ${ }^{7}$. Algum tempo depois, em 1873 - ano de ingresso de Freud na Faculdade de Medicina - Fechner publica o livro intitulado Algumas ideias para a história da criação e do desenvolvimento dos organismos, no qual ele formula, dentro do campo da psicofísica, o princípio da tendência à estabilidade. É a este livro que Freud faz referência por citação direta logo nos primeiros parágrafos de Além do princípio do prazer (1920, $A E$, p. 08; $S A$, p. 218).

Para Fechner os impulsos conscientes (bewusste Antriebe) estão sempre relacionados ao prazer ou à dor, mas estes últimos podem ser também considerados como relações respectivamente estáveis e instáveis em termos psicofísicos. Nesse sentido, sua hipótese é que todo movimento psicofísico que se eleve acima do limiar da consciência é marcado pelo prazer na medida em que se aproxima da estabilidade completa e pelo desprazer na medida em que se desvia dessa estabilidade ${ }^{8}$.

$\mathrm{Na}$ primeira frase de Além do princípio do prazer, Freud afirma: "Na teoria psicanalítica adotamos sem reservas o suposto de que o decurso dos processos anímicos é regulado automaticamente pelo princípio de prazer” (1920, $A E$, p. 7; $S A$, p. 217). O efeito desta adesão de Freud ao princípio formulado por Fechner é o que gostaríamos de explorar aqui. Todo o desenvolvimento de Além do princípio do prazer depende desta adesão. Só se pode postular um "além” do princípio de prazer na medida em que o próprio princípio já está afirmado. Ou seja, não houvesse um princípio de prazer, não faria sentido pensar qualquer "além" do princípio. Esse aspecto pode parecer à primeira vista algo corriqueiro, mas começa a se mostrar absolutamente essencial quando percebemos, juntamente com Max Schur, o médico de Freud, que "a aplicação do princípio de constância enunciado por

\footnotetext{
${ }^{5}$ Cf. ROZA, Introdução à Metapsicologia Freudiana. Volume 3, p. 166-168

${ }^{6} \mathrm{Na}$ esteira da tradição alemã dos estudos de psicologia e neurologia, Freud jamais deixará de defender a explicação naturalística dos fenômenos psíquicos, chegando a afirmar diversas vezes em sua obra que o corpo doutrinário da psicanálise um dia deverá ser assentado sobre seu fundamento orgânico (STEIN, $A$ desconstrução do eu, p. 190).

${ }^{7}$ Cf. FECHNER, Elemente der Psychophysik - Erster Teil, p. 32.

${ }^{8}$ FECHNER, Einige Ideen zur Schöpfungs- und Entwickelungsgeschichte der Organismen, p. 94
} 
Fechner (...) constitui um elemento essencial da teoria freudiana do funcionamento do aparelho psíquico"'.

Ao realizar o gesto de ratificar o princípio formulado por Fechner, Freud apresenta a condição fundamental para se pensar uma teoria da pulsão de morte. Não seria possível pensar a pulsão de morte freudiana sem o conceito de prazer como tendência à estabilidade ou redução de tensão. Por outro lado, e esse aspecto nem sempre é salientado, a afirmação do princípio de prazer coloca as novas especulações sobre a pulsão de morte em relação direta com a primeira tópica, pois esta emerge precisamente da afirmação da tendência à estabilidade.

Na carta de Freud à Breuer (29 de junho de 1892) encontra-se o primeiro registro do princípio da tendência à estabilidade como "tese de constância da soma de excitação" (1892, $A E$, p. 183). Ou seja, ainda na fase de elaboração dos primeiros estudos sobre a histeria, a tendência à estabilidade é convocada como um dos elementos centrais, juntamente com a memória, na composição de uma possível etiologia. Aproximadamente três anos após esta carta, no Projeto de Psicologia, de 1895, Freud apresenta a ideia de um princípio de "inércia neuronal", o qual enuncia que os neurônios procuram aliviar-se da quantidade Q (1895, $A E$, p. 340). Esse princípio explicaria tanto a função da descarga quanto a fuga do estímulo, aos quais Freud denomina de função neurônica primária ${ }^{10}$. Ocorre que nem sempre, mesmo com a conservação das vias de escoamento, é possível manter-se afastado das vias de excitação, seja pela quantidade exorbitante, seja pelo fato de que os estímulos internos (ao contrário dos externos) não oferecem possibilidade de fuga. Essa é a condição do funcionamento neuronal que nos leva a compreender a distinção proposta por Freud entre neurônios permeáveis $(\varphi)$, impermeáveis $(\psi)$ e de percepção $(\omega)^{11}$.

Poderíamos discutir sobre o valor hermenêutico dessas passagens, uma vez que se tratam de uma carta, com conteúdo confidencial, e de um projeto tão logo rejeitado por Freud e cuja publicação póstuma, em 1950, devemos à Marie Bonaparte. Porém, toda e qualquer dúvida sobre a importância do princípio de constância ainda na aurora da psicanálise é eliminada, na medida em que ele é incorporado e validado no segundo volume da obra-prima de Freud, A Interpretação dos Sonhos. No capítulo sobre a psicologia dos processos oníricos, especialmente no item "C" - Acerca do cumprimento dos desejos, Freud retoma e desenvolve a ideia de "aparelho psíquico" (psychischer Apparat) sob a perspectiva da psicologia do desenvolvimento:

\footnotetext{
${ }^{9}$ SCHUR, La mort dans la vie de Freud, p. 384

${ }^{10}$ ROZA, Introdução à Metapsicologia Freudiana. Volume 1, p. 88

${ }^{11}$ Sobre a relação entre a consciência perceptiva e os neurônios ômega, consultar: Raffaelli, Psicanálise e percepção, p. 80: “Tais neurônios ômega atuariam como 'orgãos de percepção', sendo destituídos de memória, e sua função precípua seria a da 'indicação de realidade’ para o sistema psi, e assim, percepção igual a consciência, cronologicamente a primeira teoria da percepção na obra de Freud”.
} 
Nós nos aprofundamos [VII.C] na ficção [in die Fiktion] acerca de um aparelho psíquico primitivo, cujo trabalho (Arbeit) foi regulado através do esforço para evitar a acumulação de excitação e se manter sem estímulos (erregungslos) o tanto quanto possível (1900, $A E$, p. 557; $S A$, p. 568).

Com base nesse princípio, a primeira e mais simples construção do aparelho psíquico segue o modelo do aparelho reflexo. Entretanto, as urgências da vida e perturbações das necessidades corporais passam a exigir mecanismos mais complexos de drenagem sob a forma de expressão emocional. É desde as repetições de vivências de satisfação e de insatisfação que se dá a possibilidade, por via da identidade perceptiva, da retenção sob a forma de memória.

Com isso, parece-nos demonstrado que Freud não apenas conhecia o princípio da tendência à estabilidade, mas igualmente debateu sobre ele com Breuer, adotou-o em seu Projeto de Psicologia e incorporou-o à sua teoria do aparelho psíquico, justamente em uma das partes mais importantes da Intepretação dos Sonhos. Assim sendo, quando Freud remete expressamente ao princípio da tendência à estabilidade em Além do princípio do prazer, o que ele faz, no fundo, é ratificar uma tese fundamental que ele não pretende abandonar. Isso por uma razão capital: o princípio de prazer é a base de sustentação da primeira tópica e, mais do que isso, está na base da própria definição do inconsciente. Não fosse assim, como poderíamos conceber o inconsciente (recalcado) tal como Freud o apresenta sem a dimensão teleológica do princípio da tendência à estabilidade? A resposta mais plausível a essa questão é que seria impossível, sem o princípio de prazer, pensar o inconsciente em suas definições tópica, dinâmica e econômica. Não é à toa que Freud retoma a exposição metapsicológica do famoso artigo $O$ inconsciente (1915), no primeiro parágrafo de Além do princípio do prazer. "A nosso juízo, uma exposição que além dos aspectos tópico e dinâmico aprecia esse outro aspecto, o econômico, é a mais completa que possamos conceber nesse momento" (1920, $A E$, p. 7; $S A$, p. 217).

Ora, diante de novas observações e novos casos clínicos que colocavam em dúvida a pertinência da natureza fundamental do princípio de prazer, Freud tinha basicamente duas alternativas. Ou bem (1) ele reconhecia que o princípio de prazer não é fundamental - o que representaria a ruína de sua teoria do aparelho psíquico e, portanto, levaria à necessidade de uma reformulação completa da teoria da libido e da própria psicanálise; ou bem (2) ele mantinha o princípio do prazer no registro da exposição metapsicológica do inconsciente, porém, revisando o dualismo pulsional da primeira tópica, o que possibilitaria incorporar os fenômenos de desprazer produzidos pela recorrência da compulsão à repetição. Qualquer uma destas opções teria um preço a se pagar. Como é consabido, Freud optou pelo segundo caminho e retornou ao campo das especulações biológicas e neurológicas, tal como ele o havia feito à época do Projeto de 1895. 


\subsection{A compulsão à repetição como ponto de inflexão teórica}

Continuamos nossa abordagem na ordem do texto freudiano, procurando colocar em relevo as intenções expressas no texto e os recursos expositivos utilizados por Freud. Nos dois capítulos seguintes (2 e 3), ele evidencia a necessária revisão da primeira tópica, sem abandonar o seu modelo de aparelho psíquico e a formulação do inconsciente. O método utilizado por ele consiste em apresentar exemplos oriundos da observação e da clínica que produziram uma tensão com o princípio de prazer: as neuroses e sonhos traumáticos, o jogo infantil e as neuroses de transferência. Propomos um exame destes exemplos seguindo a ordem do texto de Freud.

\section{(a) As neuroses traumáticas e os sonhos traumáticos}

O primeiro exemplo apresentado é o das neuroses traumáticas, ou seja, das neuroses que sobrevêm após comoções mecânicas e acidentes de toda sorte. Neste grupo de neuroses encontram-se as neuroses de guerra, cujos efeitos ainda eram profundamente sentidos como consequência dos horrores da Primeira Guerra mundial. Vale lembrar que a neurose de guerra foi o tema do 5ํ Congresso Psicanalítico Internacional, realizado em Budapeste entre 28 e 29 de setembro de 1918. Nesse Congresso estiveram presentes os representes oficiais das principais autoridades do Ministério da Guerra austríaco. A psicanálise havia sido procurada pelas instâncias oficiais porque os tratamentos com eletroterapia não ofereciam resultados duradouros (Freud, 1919b, $A E$, p. 205).

$\mathrm{Um}$ ano depois, foram reunidas as principais conferências desse evento sob o título Sobre as neuroses de guerra, cuja introdução, escrita por Freud, resultou publicada igualmente no volume XVII das Obras Completas (1919b, AE, p. 205-208). Através da sua exposição, fica bastante claro que as neuroses de guerra serviram de pretexto aos seus adversários para atacar a tese sobre a natureza dita libidinal ou sexual das neuroses. É possível imaginar o clima de tensão que invadia a instituição psicanalítica desde o ano anterior. Tratava-se de fazer uma defesa da psicanálise, mas o tema carecia de uma resposta final. Freud procura mostrar que os casos de neurose de guerra não demonstravam a incorreção da doutrina da etiologia sexual das neuroses, mas reconhece que esta última foi formulada para a análise das neuroses de transferência em tempos de paz, de maneira que ela "tropeça em dificuldades quando se quer aplicá-la a outro grupo de neuroses que reunimos sob o nome de 'narcisistas"” (1919b, $A E$, p. 207).

Quando Freud introduz o tema em Além do princípio do prazer, é imperioso lembrar que se tratava de um dos maiores desafios da psicanálise daquele momento. Como o primeiro parágrafo deixa claro, Freud via nas neuroses traumáticas, apesar das dificuldades explicativas que ela portava, ao menos um esclarecimento. 
A horrorosa guerra que acaba de terminar provocou [a neurose traumática] em grande número, e ao menos pôs fim ao intento de atribui-la a uma deterioração orgânica do sistema nervoso por ação de uma violência mecânica (1920, $A E$, p. 12; $S A$, p. 222).

A nova hipótese explicativa é que o paciente sofre com uma fixação ao trauma. Isso podia ser demonstrado tanto pelos sonhos quanto pelo estado em vigília da pessoa acometida por esse tipo de neurose. A lembrança traumática ocorre em vigília e de forma espontânea. Da mesma forma, os sonhos reconduzem o paciente uma ou outra vez às circunstâncias do evento traumático, com o que ele se desperta com terror. Freud termina por reconhecer que, nesses casos, a própria função do sonho resulta afetada e desviada de seus propósitos (1920, $A E$, p. $14 ; S A$, p. 224). Mais adiante no texto, Freud reforça que os sonhos traumáticos se distinguem dos sonhos de angústia (ou punitivos) - os quais eram considerados como sonhos que realizam não o desejo proibido, mas o desejo da consciência de culpa que reage frente à pulsão reprovada (1920, $A E$, p. $32 ; S A$, p. 242). "Devemos admitir pela primeira vez uma exceção à tese de que o sonho é o cumprimento de um desejo”. (1920, $A E$, p. 32; $S A$, p. 242). Em outros termos, os sonhos traumáticos impõem uma revisão até mesmo sobre a doutrina da interpretação dos sonhos, a qual deve aceitar, doravante, a possibilidade de um desvio sob a forma de fixação ao trauma. Em Além do princípio do prazer, Freud atribui ao retorno do traumático, sob a forma de sonho ou de recordação, uma natureza compulsiva de ordem pulsional anterior ao princípio do prazer.

\section{(b) O jogo infantil - fort-da}

O segundo exemplo explorado por Freud não decorre da clínica, como o primeiro, mas da observação direta do seu neto Ernst, de um ano e meio, no período em que residiram sob o mesmo teto. A inserção dessa observação familiar entre casos clínicos gera indagações que nos reportam ao modo como Freud vivenciou o problema do legado da psicanálise. Embora este elemento "bio-tanato-gráfico" destacado por Derrida ${ }^{12}$ seja de fundamental importância para compreender uma possível revisão teórica da psicanálise, optamos neste artigo por restringir o exercício hermenêutico à compreensão textual do exemplo em questão.

O jogo descrito por Freud e apelidado posteriormente de Fort-da tornou-se um marco emblemático para a psicanálise infantil. À diferença do caso Hans, um menino de cinco anos (1909, $A E$, pp. 7-118; $S A$, pp. 13-123) e Sergius Pankejeff (o "homem dos lobos"), atendido em idade adulta (1918, $A E$, pp. 9-112; $S A, 129-231)$, o exemplo do Fort-Da apresentado por Freud dizia respeito a um bebê de 18 meses. O fato de que ele era capaz de

${ }^{12}$ DERRIDA, La Carte Postale, p. 357 
produzir um jogo enigmático, pronunciando sílabas, antes mesmo da capacidade plena de articulação da fala, desperta o interesse de Freud e inaugura um verdadeiro paradigma para a psicanálise infantil.

Retomamos aqui a descrição do exemplo (1920, $A E$, pp. 14-16; $S A$, p. 224-226). Segundo Freud, a criança apresentava um desenvolvimento normal e pronunciava apenas algumas poucas palavras inteligíveis, bem como sons significativos que eram compreendidos pelos que o rodeavam. Parecia ter boa relação com os pais e com a serviçal (Dienstmädchen). Elogiavam o seu caráter “judicioso”. Obedecia às proibições e não incomodava durante a noite. Sobretudo, não chorava quando a sua mãe o abandonava durante horas, mesmo tendo grande ternura por ela. Possuía, porém, o hábito de jogar para longe de si, a um canto do quarto (in eine Zimmerecke) ou abaixo de uma cama (unter eine Bett) etc., todos os pequenos objetos que estavam a seu alcance. Por vezes se tornava incômodo, pois não era fácil juntar seus joguetes. Acompanhando a ação de jogar esses objetos, com interesse e satisfação, o menino proferia um forte e prolongado som "o", que segundo o juízo da mãe, não era uma interjeição, mas significava "fort", que significa "lá”. É então, através da mãe, que Freud se dá conta de que se tratava de um jogo ${ }^{13}$.

Posteriormente, Freud observou que o menino fazia outro uso de seus objetos além de os jogar para longe. Certo dia, o menino manuseava um carretel de madeira (eine Holzspule), o qual estava enrolado em um ou fio (der Bindfaden). Não lhe ocorreu de arrastá-lo pelo chão, mas jogou o carretel preso pelo fio com destreza por sobre a borda de sua caminha (Bettchen) e depois puxou o carretel por fora da cama pelo fio, cumprimentando o seu aparecimento com um “da” (aqui). Para Freud, o jogo completo compunha-se, portanto, de dois movimentos, um jogo de desaparecimento (Verschwinden) e de retorno (Wiederkommen). Em nota de rodapé, Freud complementa que esse fato se comprova por outra observação, segundo a qual a mãe foi saudada pelo menino quando de seu retorno, depois de horas de ausência, com a expressão “bebê ô!”. Essa expressão somente se fez compreensível porque o menino havia descoberto a sua própria imagem em um espelho do vestuário que ia até o chão, com o qual ele produzia o mesmo jogo. (1920, $A E$, p. $15 ; S A$, p. 225).

A interpretação que Freud em seguida nos oferece é que o jogo estava relacionado com a grande conquista cultural no menino, através da renúncia à satisfação pulsional, de admitir sem protesto a partida da mãe. O menino compensava, ou se indenizava (entäschdigte sich), significando por si mesmo o desaparecer e retornar com os objetos que estavam a seu alcance. Freud formula então a questão que lhe interessa no cerne de Além

\footnotetext{
${ }^{13}$ Esse detalhe apresentado no relato de Freud não pode passar despercebido. É a mãe quem esclarece o significado da letra pronunciada pela criança como "lá" e permite a Freud, como pediatra nesta ocasião, a interpretação do jogo. Só há jogo porque já se ingressou no campo da significação. Na pediatria e psicanálise de crianças, é aos pais e como cuidadores, ou seja, em relação, que podemos nos questionar sobre a produção de significado no jogo.
} 
do princípio do prazer. Considerando que a partida da mãe não é algo agradável ou indiferente, como se concilia com o princípio do prazer que se repita na forma de jogo essa vivência penosa? (1920, $A E$, p. 15; $S A$, p. 225).

Uma resposta hipotética oferecida por Freud é que a partida é a condição prévia da satisfação pela reaparição, a qual seria o genuíno propósito do jogo. No entanto, assinala Freud, isso contradiz a observação de que o primeiro ato era realizado isoladamente e com frequência incomparavelmente maior do que o jogo inteiro (1920, $A E$, p. 15; $S A$, p. 225-226).

Sobrevém aqui uma dificuldade - e até mesmo uma possível contradição - no texto de Freud. Em nenhum momento da descrição do relato, o fato de o menino jogar longe seus objetos e brinquedos aparece como desprazeroso. Ao contrário, ao jogar os objetos o menino proferia "fort" com "expressão de interesse e satisfação" (mit dem Ausdruck von Interesse und Befriedigung) (1920, $A E$, p. 14; $S A$, p. 224). O desprazer narrado é unicamente o das pessoas que tinham de juntar os objetos. Ou seja, Freud perdeu a oportunidade, ao menos nesse texto, de examinar como Ernst foi capaz de transformar uma vivência de sofrimento (de separação da mãe) em vivência integralmente prazerosa através do jogo. Talvez a experiência vivida por Ernst esteja mais próxima daquela que Freud descreve acerca de outros jogos e vivências estéticas como a dramatúrgica: “(...) ainda sob o império do princípio de prazer existem suficientes meios e vias para converter em objeto de recordação e elaboração psíquica o que em si mesmo é desprazeroso" (1920, $A E$, p. 17; $S A$, p. 227). É precisamente esta intuição que Melanie Klein desenvolve ao demonstrar por meio de novos exemplos observados que a repetição contribui para que o bebê supere seus sentimentos de perda e tristeza ${ }^{14}$.

No entanto, não estava em questão admitir que o caso de Ernst era regido pelo princípio do prazer, uma vez que o menino apresentou através do jogo recursos para elaboração psíquica de algo desprazeroso. Freud opta por duas outras interpretações, pois seu objetivo era colocar em desafio o próprio princípio do prazer. A primeira é que a posição passiva da criança pode ser transformada em ativa mediante a pulsão de dominação (Bemächtigungstrieb), independentemente da recordação. A segunda é de que o jogo seria a expressão de um impulso de vingança (Racheimpulses) recalcado (1920, $A E$, p. 16; $S A$, p. 226). Ou seja, independentemente do prazer, as tensões e impulsos se reorganizam e encontram no jogo um canal simbólico de satisfação.

Ainda que este não pareça ser o caso de Ernst (nada no exemplo permite auferi-lo), aceitaremos de Freud, ex concessis, que é possível encontrarmos certos casos de jogos infantis nos quais a repetição de atos ansiogênicos e desprazerosos ocorrem de forma isolada, ou seja, não produzem prazer ou têm conexão com a pretensão de alívio posterior. Em outras palavras, o esforço de processar psiquicamente algo desconfortável e de se apoderar disso pode se exteriorizar de modo primário e independentemente do princípio

${ }^{14}$ KLEIN, On Observing the Beahviour of Young Infants, pp. 110-111 
do prazer. Nesse sentido, o exemplo de um jogo desprazeroso complementa o exemplo das neuroses traumáticas e nos coloca diante da repetição compulsiva de um pensamento ou de uma lembrança dolorosos.

\section{(c) A repetição nas neuroses de transferência e a Wiederholungszwang}

O terceiro exemplo oferecido por Freud em Além do princípio do prazer é o das repetições manifestas em casos de neuroses de transferência. A meta de tornar consciente o inconsciente, através da recordação, encontra todo tipo de resistências na clínica. Ao invés de recordar (erinnern) o conteúdo da vivência que fora recalcado, o neurótico vê-se forçado a repetir (wiederholen) o recalcado. Freud faz referência em nota de rodapé (1920, $A E$, p. $18 ; S A$, p. 228$)$ ao seu trabalho intitulado Recordar, repetir e reelaborar. Com efeito, nesse artigo de 1914 já se encontra uma descrição da natureza compulsiva do paciente que repete - ou atua sobre - o recalcado, conteúdo cuja recordação é dificultada pela resistência. O paciente "repete tudo o que já prevalece desde as fontes do seu recalcado já em sua essência evidente: suas inibições e atitudes inviáveis, seus traços patológicos de caráter. Ademais, ele repete também durante o tratamento todos os seus sintomas”. (1914, $A E$, p. 153). Nesse sentido, o tema da compulsão à repetição (Zwang zur Wiederholung ou Wiederholungszwang), tratado de forma preliminar em Recordar, repetir e reelaborar, é retomado em Além do princípio do prazer a fim de compor os exemplos apresentados, juntamente com as neuroses traumáticas e o Fort-da.

Ao reintroduzir a Wiederholungszwang como questão, Freud trata da necessidade de livrar-se de um "erro" que consistiria em tomar a luta de enfrentamento contra as resistências como um enfrentamento de uma resistência do inconsciente - ou o recalcado. Segundo Freud, não seria o recalcado quem oferece resistência aos esforços do tratamento, mas os mesmos estratos superiores da vida psíquica que levaram a cabo o recalque (1920, $A E$, p. $19 ; S A$, p. 229). Logo em seguida, Freud sinaliza que esta questão pode ser pensada mais claramente, não em termos de um conflito entre o consciente e o inconsciente, mas entre um "eu” coerente e o recalcado, antecipando uma reflexão típica da segunda tópica. Ora, o "eu" possui ele mesmo uma dimensão inconsciente recalcada, que aqui Freud chama de "núcleo do eu" (Kern des Ichs). "Evitamos a obscuridade se colocamos em oposição, não o consciente e o inconsciente, senão o eu coerente e o recalcado. Muito do eu é seguramente inconsciente, justamente o que se pode chamar o 'núcleo do eu' (1920, $A E$, p. $19 ; S A$, p. 229$)^{15}$.

\footnotetext{
${ }^{15}$ Desde então, Freud hesitará em seus escritos sobre qual seria efetivamente o núcleo do eu. Em 1923, em uma nota de rodapé de $\mathrm{O}$ eu e o isso, Freud corrige essa tese. Como é o "eu" que possui a função do exame de realidade, "somente se pode reconhecer como núcleo do eu o sistema P-Cc [ou percepção-consciência]" (1923, $A E$, p. 30; $S A$, p. 296). Mais tarde, porém, em um pequeno texto intitulado $O$ humor, Freud retorna a essa mesma questão. Sem realizar nenhuma "correção" expressa, ele afirma: "Este eu não é nada simples, pois
} 
Freud afirma a partir desta observação inicial que a resistência do analisado parte do seu “eu”, enquanto a compulsão à repetição adscreve-se ao recalcado inconsciente (1920, $A E$, pp. $19-20 ; S A$, p. 230). Há segundo Freud uma diferença entre a resistência do eu e a compulsão à repetição. Enquanto a resistência do eu consciente e pré-consciente está a serviço do princípio do prazer (salvaguardando o eu do desprazer decorrente da liberação do recalcado); a compulsão à repetição, responsável pela exteriorização forçosa do recalcado (die Kraftäußerung des Verdrängten), provoca desprazer ao eu.

Freud faz uma parada nesse ponto para retomar uma análise anterior ${ }^{16}$. Essa classe de desprazer advinda da exteriorização do recalcado pode ser considerada sob a vigência dos múltiplos sistemas do aparelho psíquico (consciente, pré-consciente e inconsciente). Nesse sentido, o fato de que a compulsão à repetição provoca desprazer não contradiria o princípio de prazer, uma vez que o desprazer provocado em um sistema pode corresponder à satisfação em outro (1920, $A E$, p. 20; $S A$, p. 230). Não obstante essa interpretação, o que Freud sinaliza logo em seguida - agora de forma inteiramente nova - é que a compulsão à repetição devolve também vivências passadas que não comportam qualquer possibilidade de satisfação, nem no passado, nem no presente, mesmo em relação às moções recalcadas.

Há certas dimensões, prossegue Freud, como a perda do amor (der Liebesverlust) ou a falha (das Mißlingen) que deixam a sequela de um dano permanente na autoestima - ou sentimento de si (Selbstgefüh) - como uma cicatriz narcísica (narzißtische Narbe). Seria este o mais poderoso aporte contra o "sentimento de inferioridade" (Minderwertigkeitsgefüh) dos neuróticos. (1920, $A E$, p. 20; $S A$, p. 230). O texto não poderia ser mais claro. Até esse ponto da análise de Freud, não se consegue compreender, afinal de contas, o que está em jogo, pois aparentemente, os casos de repetição nas neuroses transferenciais podiam igualmente ser pensados pelo princípio do prazer. A introdução desta dimensão narcísica afetada, desta ferida narcísica, bem como do sofrimento profundo que dela decorre, o qual vem à tona sempre de novo, ou sempre já está aí com toda a sua conformação infantil, inclusive com a sua peculiar falta de recursos para uma

alberga como seu núcleo uma instância particular, o supereu, com o que conflui muitas vezes a ponto tal que não os podemos distinguir entre si”. (1927, $A E$, p. 160; $S A$, p. 280). A questão é complexa justamente porque ela se localiza no centro da segunda tópica e se refere finalmente à possibilidade de justaposição entre as duas tópicas - uma harmonia que até hoje é objeto de discussão. Sem a pretensão de resolver essa questão, talvez seja útil para nossa hermenêutica admitir, em primeiro lugar, a ideia de que o eu preponderantemente - se encarrega da função de exame de realidade, como afirmado em $O$ eu e o isso. Em segundo lugar, entretanto, é preciso reconhecer que, desde o "núcleo do eu", essa função não opera sozinha, pois parte dela é investida pelas moções recalcadas e pelas forças de recalcamento do supereu.

${ }^{16}$ Freud apenas alude a esta análise, sem citá-la. James Strachey identifica em nota de rodapé explicativa, na edição standard, que esse trecho está nas Conferências de Introdução à Psicanálise. Com efeito, no texto revisado da $14^{a}$ Conferência - O cumprimento do desejo, Freud assinalou a necessidade de se perguntar a "quem" o cumprimento do desejo no sonho brinda com prazer, pois o cumprimento do desejo pode ser prazeroso de um lado e penoso de outro (1916, $A E$, pp. 197-198; $S A$, p. 219). 
reelaboração, é o que está verdadeiramente em jogo. O trauma em sua dimensão narcísica promove fixação e retorna sem qualquer sinal de prazer.

Ainda em relação aos últimos parágrafos do terceiro capítulo, Freud acrescenta que tais fenômenos de transferência dos neuróticos são também encontrados na vida das pessoas não neuróticas. Há algo como um “destino” que as persegue, uma “característica demoníaca" de sua vivência, cuja fatalidade a psicanálise já julgava como autoinduzida e determinada por influxos da infância (1920, $A E$, p. 21; $S A$, p. 231). Assim a compulsão à repetição se exterioriza mesmo em casos de pessoas que nunca apresentaram sinal de um conflito neurótico mediante formação de sintomas. Freud nos apresenta alguns exemplos desse "eterno retorno do mesmo" (ewige Wiederkehr des Gleichen), como os benfeitores que amarguram a ingratidão de seus protegidos depois de passado algum tempo; pessoas que veem toda a sua amizade terminada depois de uma traição; pessoas que muitas vezes elevam alguém à condição de autoridade para em seguida destroná-la e substitui-la por outra; amantes cuja relação terna passa sempre pelas mesmas fases e desemboca em idêntico final. (1920, $A E$, pp. 21-22; $S A$, p. 231-232). O que surpreende mais é que muitos desses casos não resultam de uma conduta ativa (a ser reportada a um traço de caráter), mas são vivenciados passivamente, ou seja, de forma subtraída ao poder da pessoa (1920, $A E$, p. 22; $S A$, p. 232).

Nesse ponto da exposição, Freud sente-se seguro para reunir sob a categoria da compulsão à repetição, que se instaura mais além do princípio do prazer, os três tipos de exemplo explorados até então: (a) a neurose traumática e o sonho traumático; (b) a impulsão (Antriebe) ao jogo; (c) a repetição na transferência e o destino fatal dos seres humanos.

Já na primeira afirmação deste mais além, a advertência de Freud é imediata. Raros são os casos em que se podem apreender "puros" (rein) - sem a participação de outros motivos - os efeitos da compulsão à repetição. No jogo, a compulsão à repetição e a satisfação pulsional direta podem vir entrelaçadas (1920, $A E$, p. 22; $S A$, p. 232). Ademais, como vimos, este parece ser de fato o Fort-da de Ernst. Acrescenta Freud (1920, AE, p. 23; $S A$, p. 233) que também os fenômenos de transferência, por estarem a serviço da resistência do eu, aferram-se ao princípio do prazer. O mesmo ocorre com os sonhos traumáticos e as compulsões de destino. Ou seja, todos os exemplos estudados não apresentam a compulsão à repetição “pura”, mas sempre misturada com outros elementos, eventualmente vivenciados com prazer. Acrescenta-se ainda a esses exemplos os casos de sadomasoquismo, que mesclam experiências de prazer e desprazer, inclusive transformando os sinais de desprazer em prazer (1920, $A E$, pp. 54-55; $S A$, p. 262-263).

Por fim, Freud considera suficiente a exposição feita para justificar a hipótese de compulsão à repetição como mais originária (ursprünglicher), mais elementar 
(elementarer), mais pulsional (triebhafter) que o princípio de prazer (1920, $A E$, p. 23; $S A$, p. 233). Por outro lado, isso não significa que o princípio do prazer é extirpado da economia psíquica, pois desse modo a teoria do aparelho psíquico correria o risco de desmoronar. $\mathrm{O}$ princípio do prazer é "empurrado para o lado" (zur Seite geschobene LustPrinzip) pela compulsão à repetição ( $S A$, p. 233) - e não "destronado" ou "dominado", como sugerem respectivamente as traduções Amorrortu (1920, $A E$, p. 23) e Imago (Freud, 1998, p. 30). Cabe doravante compreender o que é e de onde vem essa pulsão mais original e elementar do que o princípio do prazer.

\subsection{A pulsão de morte como um conceito especulativo do campo biológico}

A parte que vai do quarto ao sétimo capítulo pode ser interpretada como o terceiro e último movimento de Além do Princípio do Prazer. Nessa última parte, Freud apresenta um desenvolvimento que integra a compulsão à repetição na metapsicologia através da postulação da pulsão de morte.

Pode ser útil à hermenêutica dessa parte do texto uma rápida alusão ao seu contexto de produção. Em uma carta enviada a Karl Abraham no dia 11 de novembro de 1917, praticamente dois anos e meio antes da conclusão de Além do princípio do prazer, Freud indicava a sua intenção de aproximar a psicanálise ao evolucionismo, a partir das teorias de Lamarck e Darwin ${ }^{17}$. Com efeito, nesta carta, Freud conta a Abraham sobre uma conversa que teve com Ferenczi, na qual falaram sobre colocar Lamarck no terreno psicanalítico e "mostrar que sua 'necessidade', que forma e transforma os órgãos não é outra coisa do que o poder da representação inconsciente sobre o próprio corpo (...)"18. Desta maneira ficaria explicada a "finalidade", ao mesmo tempo em que essa reflexão serviria de complemento à psicanálise. Esta carta permite-nos situar um período em que as preocupações de Freud com a metapsicologia o reaproximaram da especulação biológica.

A redação dessa parte do texto foi interrompida mais de uma vez. A primeira versão foi iniciada em março de 1919 e Freud ainda trabalhava no manuscrito na metade daquele ano, como atesta a carta que ele enviou à sua filha, Anna Freud, no dia 21 de julho de $1919^{19}$. Insatisfeito com o resultado do texto, Freud o retoma no inverno de 1920 e termina o livro, depois de ter introduzido inúmeras modificações ${ }^{20}$.

"O que segue agora é especulação" (Was nun folgt, ist Spekulation). (AE, 1920, p. 24; $S A$, p. 234). É Freud mesmo quem utiliza o termo "especulação” ao iniciar o quarto capítulo. Reconhece, portanto, que estamos entrando em um terreno especulativo, sem

\footnotetext{
${ }^{17}$ SCHUR, La mort dans la vie de Freud, p. 392

${ }^{18}$ FREUD; ABRAHAM, Correspondencia (1907-1926), p. 292-293

${ }^{19}$ FREUD, S; FREUD, A. Correspondência (1904 - 1938), p. 159

${ }^{20}$ SCHUR, La mort dans la vie de Freud, p. 393
} 
provas experimentais, com o pretexto de dar uma resposta satisfatória aos exemplos de compulsão à repetição.

\section{(a) O trauma como ruptura da proteção antiestímulo}

A primeira parte do exercício especulativo proposto por Freud consiste em explicitar a natureza neurológica do trauma, em convergência com a sua teoria do aparelho psíquico. Inicialmente, Freud retoma, em terminologia metapsicológica, a tese de que a consciência não é o caráter mais universal dos processos psíquicos, senão apenas uma de suas funções, como operação do sistema perceptivo $P$-Cc. Na medida em que percebe a partir de excitações externas e internas, o sistema $P-C c$ encontra-se na fronteira do exterior e do interior (1920, $A E$, p. $24 ; S A$, p. 234). Todos os processos excitatórios, mesmo de outros sistemas, deixam sequelas, rastros ou marcas que vêm a ser a base da memória e que não têm relação com o tornar-se consciente. Apenas no sistema $P$ - $C c$ ocorre de o processo excitatório se tornar consciente. Esse sistema singulariza-se pelo fato de que o processo excitatório deixa uma marca permanente, investida por um fator principal: o choque direto deste sistema com o mundo exterior (1920, $A E, 26 ; S A$, p. 236). A consciência surge em substituição à marca mnêmica.

Seguindo os caminhos da embriologia, Freud sublinha que o sistema nervoso central provém da ectoderme, de maneira que a matéria cinzenta brota da superfície primitiva e recebe dela suas propriedades essenciais. Assim, seria possível conceber que, por causa dos incessantes estímulos externos sobre a vesícula, sua substância se alteraria em profundidade, de modo a reagir aos processos excitatórios de maneira diversa em suas camadas mais profundas (1920, $A E$, p. 26; $S A$, p. 236). Deste modo formar-se-ia uma crosta que ofereceria as condições mais favoráveis de recepção de estímulos, não estando suscetível à modificação. Transpondo essa reflexão ao sistema $C c$, pode-se representar que a consciência funciona à base de excitações que precisam vencer uma forma de resistência por meio de facilitação (Bahnung), permitindo assim a criação de marcas permanentes. No entanto, sob o influxo de energias mais potentes, essa vesícula viva com seu estrato cortical receptor de estímulos, estaria sujeita à aniquilação caso não estivesse provisionada com uma "proteção antiestímulo" ou “escudo protetor contra estímulos” (Reizschutz). (1920, $A E$, p. $27 ; S A$, p. 237). Freud promove com essas explicações um retorno ao seu Projeto de Psicologia 1895, até então desconhecido do grande público ${ }^{21}$.

${ }^{21}$ Também no próprio círculo psicanalítico o manuscrito do projeto permaneceu por muitos anos desconhecido. Sabemos hoje que Fliess foi uma das poucas pessoas a quem Freud confidenciou o seu projeto, como se pode verificar através das cartas que este enviou a Fliess nos dias 20 de outubro de 1895 e $1^{\text {o }}$ de janeiro de 1896 (FREUD, A correspondência completa de Sigmund Freud para Wilhem Fliess (1897-1904), pp. 147-148; pp. 159-163). 
A consciência situa-se entre o exterior e o interior, de maneira que também recebe excitações desde fora e desde dentro. Ocorre essa barreira antiestímulo se posiciona frente ao mundo exterior, acionada em excitações de magnitude reduzida. Quanto às excitações internas, a proteção é impossível, e as excitações dos extratos mais profundos se propagam até o sistema de maneira direta, enquanto certos caracteres de seu decurso produzem as séries de prazer e desprazer (1920, $A E$, p. 28; $S A$, p. 237). Esta característica do aparelho psíquico faz com que as sensações de prazer e desprazer - indício de excitação interna tenham prevalência em relação aos estímulos externos. Por essa razão, diante de situações de grande desprazer, tende-se por projeção (Projektion) a tratá-los como se atuassem desde fora, na tentativa de lhes aplicar uma proteção antiestímulo (1920, $A E$, p. 28; $S A$, p. 238). Entretanto, até aqui, a explicação não contraria o princípio de prazer.

Freud volta-se, então, para as excitações externas: "Chamamos traumáticas as excitações externas que possuem força suficiente para perfurar a proteção antiestímulo”. (1920, $A E$, p. 29; $S A$, p. 239). O trauma externo pode provocar uma enorme perturbação da economia psíquica e coloca em ação no organismo todos os mecanismos de defesa. Porém, em um primeiro momento, o princípio de prazer fica suspenso, pois a inundação (Überschwemmung) do aparelho psíquico por grandes quantidades de estímulos torna urgente a tarefa de ligá-los (zu binden) e conduzi-los a uma resolução (1920, $A E$, p. 29; $S A$, p. 239).

Essa é, finalmente, a explicação que Freud reporta aos casos de neurose traumática, neurose de guerra e aos sonhos traumáticos. "Creio que podemos nos atrever a conceber a neurose traumática comum como o resultado de uma vasta ruptura da proteção antiestímulo”. (1920, $A E$, p. 31; $S A$, p. 241). Ao fazer esse gesto, Freud contrapõe-se à "doutrina do choque" (Lehre vom Schock), que situa a essência do choque na deterioração direta da estrutura histológica dos elementos nervosos - ou seja, à própria violência mecânica -, enquanto a psicanálise procura compreender os efeitos do choque - o terror e o perigo de morte - através do rompimento da "proteção anti-estímulo para o órgão anímico" (Reizschutzes für das Seelenorgan) (1920, AE, p. 31; SA, p. 241)22. O trauma, portanto, dá a pista que leva Freud a afirmar a hipótese da pulsão de morte ${ }^{23}$.

\footnotetext{
${ }^{22}$ Anos depois, em Inibição, Sintoma e Angústia, ocasião em que Freud sistematiza os tipos de angústia, ele reafirmará a tese de que "a angústia é a reação frente ao perigo” (1926, $A E$, p. 141; $S A$, p. 289).

${ }^{23}$ Há casos em que a neurose traumática não apresenta nenhuma alteração provocada por uma violência mecânica ou por motivos orgânicos. Por outro lado, há casos em que, além do trauma, há também uma lesão fisiológica. Em psicanálise, é forçoso reconhecer tal possibilidade. Sobre esse aspecto, cumpre um papel ímpar o livro de Catherine Malabou, Os Novos Feridos. De Freud à neurologia, pensar os traumatismos contemporâneos (2007), que coloca em debate inúmeros aspectos integrados aos contornos dos traumas, lesões e doenças degenerativas, a partir das novas pesquisas neurológicas, por exemplo, em torno da plasticidade neuronal. O quanto a famosa tese da "proteção anti-estímulo" pode ser comprovada
} 
O capítulo cinco prossegue a especulação iniciada no capítulo anterior. A hipótese neurológica do rompimento da proteção antiestímulo corresponde à suspensão temporária do princípio de prazer, uma vez que excitações externas inundam o aparelho psíquico. Porém, cabe ainda examinar a ausência da proteção antiestímulo para o extrato cortical receptor das excitações internas do organismo. Tais excitações dão ocasião, com frequência, a perturbações equiparáveis à neurose traumática. Resta investigar as suas fontes.

Para Freud "as fontes mais abundantes (ausgiebigsten Quellen) dessa excitação interna são as chamadas 'pulsões' do organismo" (1920, $A E$, p. 34; $S A$, p. 244). As pulsões representam todas as forças eficazes do interior do corpo que se transferem ao aparelho psíquico. Freud designa-as como o elemento mais importante (wichtigste) e a mais obscuro (dunkelste) da investigação psicológica (1920, $A E$, p. 34; $S A$, p. 244). Haveria um caráter pulsional nas exteriorizações da compulsão à repetição de natureza demoníaca, que parece lhe situar mais além do princípio do prazer. Freud apresenta, então, uma nova definição do caráter universal da pulsão, que procura mesclá-la com a compulsão à repetição, a partir do fato de que todo ser vivo morre e regressa ao inorgânico:

Uma pulsão seria então um esforço, inerente ao orgânico vivo para restaurar um estado anterior, que os vivos teriam de abandonar frente ao influxo de forças perturbadoras externas; seria uma sorte de elasticidade orgânica, ou, se se quiser, a expressão da inércia na vida orgânica. (1920, $A E$, p. 36; SA, p. 246 - Grifo no original.

O que muda nessa nova definição sobre o caráter universal da pulsão é que a pulsão, antes vista como função de mudança e desenvolvimento, agora é reconhecida por Freud como a expressão conservadora do ser vivo. A fim de corroborar a sua hipótese, Freud lança mão de exemplos biológicos, como o das migrações reprodutivas de peixes e aves, assim como os fenômenos de herança e da embriologia. As células germinais dos animais vivos estão obrigadas a repetir, ainda que de modo compendiado, as estruturas de todas as formas das quais o animal descende, ao invés de alcançar prontamente a sua formação definitiva por um caminho mais curto (1920, $A E$, p. 37; $S A$, p. 247). Freud vale-se aqui do fator adaptativo e reprodutivo para fazer valer a sua hipótese de repetição como elemento conservador da própria espécie.

Indo mais além do que os exemplos biológicos oferecidos, Freud postula uma hipótese geral para todo o ser vivo, que seria regido por uma pulsão orgânica conservadora. Se todo ser vivo morre e regressa ao inorgânico por razões internas, "a meta (Ziel) de toda

neurologicamente e deveria ser associada, de alguma forma, à neurologia contemporânea, é uma tarefa que permanece em aberto. 
vida é a morte e, retrospectivamente: o inanimado (Leblose) estava aí antes do vivo (Lebende)" (1920, AE, p. 38; SA, p. 248).

Ora, se essa é a característica universal das pulsões, como acomodar a essa definição as pulsões sexuais? Freud assume a premissa darwiniana de que todos organismos estão expostos à compulsão externa que os empurra a um desenvolvimento cada vez maior (1920, $A E$, p. 39; $S A$, p. 249). Utiliza então o exemplo das células germinais, que provavelmente conservam a estrutura originária da substância viva. Ao se soltarem do organismo principal, estas células carregam as disposições pulsionais herdadas e recém adquiridas, são preservadas em condições favoráveis, repetem o jogo a que devem sua gênese, sendo uma parte delas aproveitada no desenvolvimento até o final, e a outra remonta ao princípio do desenvolvimento (1920, $A E$, p. 40; $S A$, p. 249). Embora conquistem apenas uma prolongação do caminho até a morte, essas células trabalham contra o fenecimento da substância viva. Encontraremos nelas uma função conservadora na medida em que espelham estados anteriores da substância viva, porém em sentido mais amplo, pois conservam a vida por lapsos mais largos. Haveria, portanto um ritmo hesitante (Zauderrhythmus) na vida dos organismos entre dois grupos pulsionais, que conduzem à morte ou fazem voltar até certo ponto para prolongar o trajeto da vida (1920, $A E$, p. 40; $S A$, p. 250).

\section{(c) O dualismo pulsional e o princípio de Nirvana}

Uma vez apresentada a tese biológica de um "ritmo hesitante" de duas pulsões nos organismos, fica preparado o terreno para a sua caracterização como pulsões de vida e pulsões de morte, ou entre pulsões sexuais (Sexualtrieben) e pulsões egóicas (Ichtrieben) (1920, $A E$, p. 43 e 51; $S A$, p. 253 e 261). Resta oferecer um maior esclarecimento sobre a sua distinção. Esse é o passo dado por Freud no sexto capítulo do texto. Trata-se certamente do ponto mais longínquo de sua especulação no campo biológico.

Freud introduz então uma leitura da teoria morfológica de August Weismann, sobre a distinção entre o soma mortal e o plasma germinal imortal dos organismos pluricelulares. Weismann sustentou que os organismos unicelulares são potencialmente imortais, de modo que a morte aparece somente como mecanismo de conveniência (Zweckmäßgkeit) dos organismos pluricelulares, um fenômeno de adaptação às condições vitais externas e adequada a fins (1920, $A E$, p. $45 ; S A$, p. 255). Contra essa tese, Freud apresenta a teoria de Hartmann, segundo a qual também os protozoos são mortais como arguição à ideia de que a morte seria uma aquisição tardia dos organismos vivos (1920, $A E$, p. 45; $S A$, p. 255). Nesse caso, resulta indiferente a morte natural dos protozoos, pois as forças pulsionais que transportam a vida à morte poderiam atuar neles desde o começo, cujo efeito poderia resultar oculto pelas forças de conservação da vida (1920, $A E$, p. 48). 
Com base na perspectiva morfológica, Freud pretende dar um passo em direção à perspectiva dinâmica, colocando em relevo a chamativa semelhança entre a teoria biológica da separação entre soma e plasma germinal com a diferença entre pulsões de vida e de morte. Existem ainda semelhanças entre a perspectiva dinâmica e outras teorias. A primeira delas seria a semelhança com a teoria de Ewald Hering acerca da substância viva, que distingue duas classes de processos, de orientação contraposta - o anabolismo (assimilatório) e o catabolismo (desassimilatório). (1920, $A E$, p. 48; $S A$, p. 258). Da mesma forma poderiam ser pensadas a pulsão de vida e de morte, como processos de assimilação e processos de degradação. A segunda semelhança seria com a filosofia de Schopenhauer, para a qual a morte é o genuíno resultado da vida (1920, $A E$, p. 48; $S A$, p. 258).

Depois dessas breves alusões a Hering e Schopenhauer, Freud procura acomodar a nova forma de dualismo pulsional com a sua teoria da libido - verdadeiro problema de fundo de Além do princípio do prazer. Nesse sentido, ele procura fazer uma rápida narrativa sobre a descoberta da diferença entre pulsões egóicas de autoconservação e pulsões sexuais dirigidas ao objeto. O conceito de sexualidade terminou por estender-se sobre muitas coisas que não se subordinavam à função estrita da reprodução. Mais tarde na Introdução ao Narcisismo - foi reconhecido que a libido não se dirige apenas ao objeto, mas pode se manter voltada a si mesma, de modo narcisista, e que o "eu" é o reservatório genuíno e original da libido (1920, $A E$, p. 50; $S A$, p. 261). Nesse sentido, Freud dá um importante passo teórico para integrar a primeira tópica: também a dimensão autoconservativa possui natureza libidinosa, ou seja, enquadram-se no campo das pulsões sexuais ou pulsões de vida. (1920, $A E$, p. 51; $S A$, p. 261). Não é à toa que o nome de Jung, defensor do monismo pulsional, aparece aqui. Freud encontra neste texto profundamente especulativo a melhor ocasião para defender a teoria do dualismo pulsional.

O texto reserva ainda um espaço para tratar do componente sádico na pulsão sexual, o qual pode, entretanto, tornar-se autônomo e governar, como perversão, toda a vida sexual da pessoa. Esse aspecto, que já havia sido abordado em Três ensaios sobre a sexualidade (1905, $A E$, p. 145-147; $S A$, p. 67-69), é aqui retomado e reformulado, desta vez sob o enfoque da pulsão de morte. O sadismo seria uma pulsão de morte apartada do eu por esforço e influência da libido narcisista (1920, $A E$, p. 52; $S A$, p. 262). No estágio da organização oral da libido, a posse amorosa coincide com a aniquilação do objeto; mais tarde a pulsão sádica se separa e cumpre a função de dominar o objeto sexual. Freud revisa aqui a tese de um sadismo original, no qual se estabelece a ambivalência amor-ódio e a partir do qual o masoquismo teria natureza complementar. Em seguida, alude à necessidade de complementar essas análises com base na hipótese de um masoquismo primário. No entanto, Freud não desenvolve essa nova perspectiva, deixando a questão provisoriamente em aberto, e apenas apresenta uma nota de rodapé, na qual cita o artigo de Sabina Spielrein publicado em 1912, Destruição como causa do vir a ser. Neste artigo, Sabina 
antecipou o sentido destrutivo do componente sádico da pulsão sexual. (1920, $A E$, p. 53; $S A$, p. 263$)^{24}$.

Depois destas análises sobre o sadismo e o masoquismo, Freud faz ainda um último apontamento que possui muita importância para o conjunto do texto. Ele parece aderir ao princípio de Nirvana, adotando a nomenclatura de Barbara Low, como sendo a tendência dominante da vida psíquica - e talvez da vida nervosa em geral - que corresponde ao rebaixamento (Herabsetzung), à manutenção constante (Konstanterhaltung), à supressão (Aufhebung) da tensão interna de estímulos (1920, $A E$, p. 54; $S A$, p. 264). O que Freud parece acrescentar a essa hipótese é a pulsão de morte, que equivaleria, sem as ligações responsáveis pelo prazer das descargas parciais, a uma descarga direta e fatal, a qual conduziria ao repouso final - o retorno ao inorgânico ${ }^{25}$.

No capítulo sete, Freud apresenta mais claramente esta ideia. As ligações, as quais substituem os processos primários pelos secundários, asseguram o império do princípio do prazer. No entanto, como tendência a serviço de uma função, que é manter o aparelho psíquico isento de excitações, ou reduzidas a um mínimo possível, o princípio de prazer participaria de uma aspiração mais universal de todo ser vivo que é retornar ao repouso do mundo inorgânico (1920, $A E$, p. 60; $S A$, p. 270). Estava Freud convencido de sua exposição? Voltemos a uma passagem do final do capítulo seis.

Poderiam perguntar-me se eu mesmo estou convencido das hipóteses desenvolvidas aqui. Minha resposta seria: nem eu mesmo estou convencido, nem peço aos demais que acreditem nelas. Parece-me que nada tem a fazer a aqui o fator afetivo do convencimento. (1920, $A E$, p. 57; $S A$, p. 267).

${ }^{24}$ Sabina havia apresentado o seu artigo em 1911 e no ano seguinte publicou-o no Jahrbuch für psychoanalytische und psychopathologische Forschungen. Esse artigo foi republicado diversas vezes e mais recentemente resgatado e rediscutido no Brasil (CROMBERG, Sabina Spielrein - Uma pioneira da psicanálise), fazendo-lhe justiça. Nele, Sabina Spielrein apresenta uma teoria do instinto que descreve as relações entre a destruição e a reconstrução, entre a ansiedade e a reprodução (SPIELREIN, Destruction as the cause of coming into being, p. 155-57), para assim dar conta de situações dificilmente explicáveis, como o sadomasoquismo e a presença deliberada da dor e do sofrimento em relações sexuais e amorosas. Segundo a psicanalista, "o alegre sentimento de vir a ser presente no impulso reprodutivo é acompanhado de resistência, ansiedade ou repugnância”, sentimento que ela atribui ao componente destrutivo do instinto sexual (Sexualinstinct). (SPIELREIN, Destruction as the cause of coming into being, p. 157).

${ }^{25}$ Apesar da adoção por Freud desta expressão, o princípio de Nirvana apresentado por Barbara Low é radicalmente diferente de um retorno ao inorgânico. No livro Psicanálise - uma breve consideração sobre a teoria freudiana, de 1920, a pioneira psicanalista britânica apresenta o princípio de Nirvana nestes termos: "É possível que repouse, mais profundamente do que o Princípio de Prazer, o Princípio de Nirvana, como se pode chamar o desejo do recém-nascido para retornar a esse estágio de onipotência, onde não existem desejos não preenchidos, no qual ele existia no ventre da mãe”. (LOW, Barbara - Psycho-analysis - A brief account on the Freudian theory, p. 73, tradução livre). 
É possível admitir que essas palavras não são apenas um recurso retórico, um ornamento ao final do texto como forma de polidez. Freud não teria manifestado esta hesitação, como ademais a manifestou difusamente, de modo menos contundente, ao longo do texto, se não tivesse, de fato, dúvidas sobre a consistência da sua tese especulativa. Para comprovar a real hesitação de Freud, basta percorrer a leitura do parágrafo em mais algumas linhas. "Não desconheço que o terceiro passo da doutrina das pulsões, este que empreendo aqui, não pode reclamar a mesma certeza do que os dois anteriores, a saber, a ampliação do conceito de sexualidade e a tese do narcisismo" (1920, $A E$, p. 57; $S A$, p. 267). Embora a afirmação do caráter regressivo das pulsões se apoie nos fatos da compulsão à repetição, Freud reconhece que a sua importância talvez tenha sido sobrestimada. (1920, $A E$, p. 57; $S A$, p. 268).

\section{O infamiliar, o masoquismo e a denegação}

Não obstante o clima de hesitação com que Freud termina Além do Princípio do Prazer, ele se mostrava inclinado a defender o novo dualismo pulsional do psiquismo (pulsão de vida e pulsão de morte). Ampliaremos nossa análise, examinando três outros textos de Freud nos quais ele descreve situações que se somam aos exemplos da pulsão de morte apontados em Além do Princípio do Prazer. São elas: o infamiliar, o masoquismo e a denegação. Nosso objetivo não é desta vez realizar uma análise sistemática de cada texto, como fizemos no ponto anterior, mas realizar uma abordagem restrita à apresentação de cada uma dessas questões, na medida em que, segundo a metapsicologia freudiana, elas são ilustrativas da pulsão de morte.

O primeiro desses temas é o chamado “infamiliar”, que Freud aborda em um texto homônimo de 1919, publicado mais ou menos na altura em que Além do princípio do prazer já se encontrava pronto. Das Unheimliche é um termo alemão dificilmente traduzível. Em português, "Das Unheimliche" poderia ser traduzido por "estranho" ou "inquientante", assim como em espanhol foi traduzido por "ominoso" (1919a, $A E$, pp. 219251). Terminamos optando pela tradução do termo por "infamiliar", seguindo a última edição do texto freudiano, comemorativa e bilíngue (Freud, 2019). O texto divide-se fundamentalmente em três partes, nas quais Freud realiza, sucessivamente, um estudo etimológico do termo, a sua apresentação sob diversos exemplos e o esclarecimento de certas dúvidas possíveis no que tange às condições do infamiliar. Interessa-nos aqui mostrar em que sentido o infamiliar se reporta aos processos de compulsão à repetição e, portanto, à pulsão de morte.

O infamiliar, produzido por uma sensação e frequentemente reportado à estética e à produção artística, diz respeito ao terrorífico (Schreckhaft) e ao que excita angústia e horror (Angst- und Grauenerregenden). (1919a, AE, p. 219; SA, p. 243). O termo heimlich, 
ou familiar, entre os seus vários significados, pode chegar a coincidir com o seu oposto, unheimlich. É, portanto, essa sensação muito dificilmente descritível, ambígua, do infamiliar que é de algum modo familiar (1919a, $A E$, p. 225; $S A$, p. 250), oculto-desvelado, segredo (Geheimnis) que sai à luz, que Freud pretende explorar em seus efeitos. Para tanto, ele procura mostrar como a produção desta sensação encontra-se possivelmente relacionada a pessoas, coisas, impressões, processos e situações (1919a, $A E, 220 ; S A$, p. 244). Ocorre nessa sensação algo como uma repetição do mesmo (Wiederkehr des Gleichen) (1919a, $A E$, pp. 230-238; SA, p. 250-261). O infamiliar define-se pelo domínio (Herschaft) da compulsão à repetição, que depende - verossimilmente (wahrscheinlich) da natureza mais íntima (innersten) das pulsões. Esse é o aspecto que liga esse texto a Além do Princípio do Prazer. A compulsão tem o poder de despejar (hinauszusetzen) o princípio de prazer, conferindo caráter demoníaco a certos aspectos da vida psíquica (1919a, $A E$, p. 238; $S A$, p. 261).

O infamiliar é produzido pelo retorno do recalcado sob a forma de compulsão que, no entanto, diferencia-se de outras formas de retorno como os sonhos, os atos falhos e os sintomas. Nesse sentido, é esclarecedora a abordagem de Ignácio Paim Filho, que designa o infamiliar como "vinculado de maneira mais intrínseca à força da pulsão que se manifesta por uma sensação", como "o impacto estético que uma obra de arte desperta no observador $^{26}$. O infamiliar integra, pela via do impacto de uma sensação, os exemplos de compulsão e, portanto, da pulsão de morte.

Passemos ao tema do sadomasoquismo. Em Além do princípio do prazer, Freud menciona a possibilidade de um "masoquismo primário" sem, no entanto, explorar esta hipótese. É precisamente o que ele procura descrever, quatro anos depois, no artigo $O$ problema econômico do masoquismo (1924, $A E$, pp. 165-176; $S A$, p. 343-354). A revisão do masoquismo, enquanto fenômeno possivelmente originário, não significa que a reversão secundária tenha sido eliminada por Freud, como avalia Bezerra de Andrade: “a adequação do problema do masoquismo à nova teoria pulsional realçou, ainda mais uma ligação biológica entre agressividade e sexualidade", apoiada na "natureza (mortífera) de um grupo de pulsões" ${ }^{27}$.

São basicamente dois aspectos que nos interessam no artigo de Freud de 1924, por serem a toda evidência um esclarecimento e complementação de Além do princípio do prazer $^{28}$. O primeiro deles diz respeito ao princípio de Nirvana, assim designado por Barbara Low (1924, AE, p. 165; SA, p. 343), que havia sido referido em Além do princípio do

\footnotetext{
${ }^{26}$ PAIM FILHO, Metapsicologia, p. 191 - 192

${ }^{27}$ ANDRADE, A metapsicologia do masoquismo em Freud e Laplanche, p. 62

${ }^{28}$ Não abordaremos aqui a classificação do masoquismo em erógeno, feminino e moral (einen erogenen, femininen und moralischen Masochismus) (1924, AE, p. 167; SA, p. 345), pois dificilmente trataríamos dessa questão sem enfrentar o problema de gênero e o lugar da mulher na psicanálise, o que nos levaria para fora dos limites deste artigo.
} 
prazer. Em $O$ problema econômico do masoquismo, Freud apresenta um novo desenvolvimento acerca desse princípio. Associado à pulsão de morte, o princípio de Nirvana sofre uma modificação no ser vivo que o torna um princípio do prazer esclarecimento que faltava em Além do princípio do prazer. Ou seja, é a libido que força a sua participação na regulação dos processos vitais ao lado da pulsão de morte. "O princípio de Nirvana expressa a tendência da pulsão de morte; o princípio do prazer representa a reivindicação da libido e sua modificação; o princípio da realidade, a influência do mundo exterior”. (1924, $A E$, p. 166; $S A$, p. 344). Ou seja, o princípio de Nirvana seria, em verdade, expressão da pulsão de morte que, sob influência da libido, é forçado a participar da regulação dos processos vitais.

Podemos ainda assinalar um segundo aspecto decisivo deste texto. Freud retorna à sua especulação biológica. "No ser vivo (pluricelular), a libido enfrenta-se com a pulsão de destruição ou de morte; esta, que impera dentro dele, queria desagregá-lo e levar cada um dos organismos elementares à condição da estabilidade orgânica”. (1924, $A E$, p. 169; $S A$, p. 347). A libido teria então uma tarefa: tornar inócua a pulsão de morte. Ao desviá-la em boa parte para fora, com a ajuda da musculatura, a pulsão recebe o nome de pulsão de destruição (Destruktionstrieb), pulsão de apoderamento (Bemächtigungstrieb), vontade de poder (Wille zum Macht) - a expressão nietzschiana aparece curiosamente aqui (1924, $A E$, p. 169, $S A$, p. 347). Um setor dessa pulsão é colocado à serviço da própria função sexual, enquanto sadismo. Outro setor, ao invés de obedecer a esse caminho que o leva para fora, permanece no interior do organismo, para então ser ligado libidinosamente com a ajuda de uma coexcitação sexual externa; é o que Freud passa a discernir como masoquismo erógeno ou originário.

Tais esclarecimentos são fundamentais para a teoria freudiana da pulsão de morte, pois explicitam que (1) a tarefa da libido - e do princípio do prazer - é dar um destino à pulsão de morte, forçá-la, de alguma maneira, a participar dos mecanismos reguladores da vida; e (2) o sadismo e o masoquismo são expressões da pulsão de morte já transformada, sob a forma de uma pulsão destrutiva, que se volta para fora ou permanece no próprio organismo com a participação de uma coexcitação externa.

Retomaremos, por último, uma terceira questão explorada por Freud - a denegação (Verneinung $)^{29}$. Tanto quanto a revisão do tema do masoquismo, a questão da denegação é explorada por Freud depois de Além do princípio do prazer. Podemos considerá-la como mais um complemento à teoria da pulsão de morte. O tema é tratado em um pequeno e intrigante artigo de Freud de 1925, A denegação, no qual Freud sinaliza para algumas observações feitas acerca desse fenômeno em que o sujeito nega, rechaça, uma ocorrência que acaba de lhe aflorar.

${ }^{29}$ Optamos pela tradução adotada por Hyppolite e Lacan em francês: la dénégation (Hyppolite, 1966, p. 528). 
O exemplo que ele dá é do paciente que diz "Agora você pensará que eu quero dizer algo ofensivo, mas realmente não tenho esse propósito", ou "Você pergunta quem pode ser a pessoa do sonho, minha mãe não é”. Ao fazermos a interpretação desta frase, podemos retirar a negação e retificá-la: "Então é a mãe” (1925, $A E$, p. 253; $S A$, p. 373). Freud retoma com esses exemplos a classificação lógico-gramatical dos juízos - que atribuem ou não propriedades a objetos, ou que atribuem ou não existência a eles. Procura, então, explorar como os juízos propriamente se formam enquanto ato intelectivo que elege uma ação motriz, conduzindo do pensar ao atuar (1925, $A E$, p. 256; $S A$, p. 376). Esse novo passo leva Freud a se perguntar pela gênese da função intelectual desde as forças pulsionais primárias que atuam sobre ela. Nesse sentido, o juízo é um desenvolvimento ulterior sobre a inclusão ou expulsão do ego, daquilo que originalmente é regido pela dinâmica pulsional. Nesse sentido, "a afirmação - como substituto da união - pertence ao Eros, e a negação sucessora da expulsão -, a pulsão de destruição”. (1925, $A E$, p. 256; $S A$, p. 376). Em outras palavras, à estrutura binária de afirmação e negação do juízo estaria associado o próprio dualismo pulsional, cuja expressão é a união ou a expulsão.

Ferenczi foi um dos primeiros a sublinhar a importância deste artigo no conjunto da obra freudiana. No artigo de 1926, O problema da aceitação de ideias desprazerosas Avanços no conhecimento do sentido da realidade, Ferenczi considera o texto de Freud como o início da psicologia dos processos de pensamento fundada na biologia, colocando em destaque que a Verneinung, enquanto negação da realidade, seria uma fase de transição entre ignorar e aceitar a realidade ${ }^{30}$. Mais tarde, no contexto da psicanálise francesa, em 1954, no Hospital Sainte-Anne, Hyppolite realizou (a convite de Lacan) uma notável exposição sobre uma possível interpretação dialética do termo Verneinung. A esta exposição, Lacan ofereceu a sua resposta e ambos os textos foram reunidos nos Escritos $I$. Nesse debate, são colocados em relevo (1) a definição freudiana da denegação como suprassunção (Aufhebung) do recalcado ${ }^{31}$ e (2) a oposição entre a denegação e a afirmação (Bejahung) originária ${ }^{32}$.

Para Freud, tratava-se mais uma vez de oferecer uma instanciação para a pulsão de morte, desta vez sob a perspectiva linguística da denegação. É possível perceber, especialmente nos textos sobre $O$ problema econômico do masoquismo e $A$ denegação, que Freud articula o dualismo pulsional de uma maneira diferente, procurando mostrar que a pulsão de morte ganha expressão sob a forma de domínio ou destrutividade, dirigindo-se ao mundo exterior ou voltando-se ao sujeito. Esse desdobramento da teoria da pulsão de morte e a sua formulação final é o que pretendemos ainda examinar.

\footnotetext{
${ }^{30}$ FERENCZI, The problem of acceptance of unpleasant ideas-advances in knowledge of the sense of reality, p. 367

${ }^{31}$ HYPPOLITE, Commentaire parle sur la Verneinung de Freud, p. 529

${ }^{32}$ LACAN, Réponse au Commentaire de Jean Hyppolite sur la 'Verneinung' de Freud, p. 384
} 


\section{A segunda tópica e a configuração final da pulsão de morte em Freud}

O ponto anterior permitiu-nos integrar outras exemplificações da pulsão de morte na obra de Freud àquelas de Além do princípio do prazer. Nosso foco de análise volta-se agora à tentativa de explicitar a configuração final da pulsão de morte a partir de duas questões. A primeira é compreender o papel do texto $O$ eu e o isso (1923) no aperfeiçoamento da teoria do dualismo pulsional. A segunda questão é examinar a configuração final da pulsão de morte a partir de O Mal-estar na Cultura (1930) e da Conferência 32 - Angústia e vida pulsional (1933).

\section{(a) O eu e isso}

Com a publicação de $O$ eu e $o$ isso, em 1923, Freud promove uma grande inovação no arcabouço teórico da psicanálise, propondo aquilo que conhecemos como Segunda Tópica. A partir dessas novas considerações, ricas em consequências para uma revisão da Primeira Tópica, Freud inclui como quarto capítulo do texto uma análise sobre "As duas classes de pulsões”. Esse é o ponto que nos interessa agora explorar.

Quatro aspectos essenciais de Além do princípio do prazer são retomados neste capítulo. O primeiro deles é a reafirmação do princípio de constância de Fechner (1923, $A E$, p. 47; $S A$, p. 313), base de sua teoria do princípio do prazer, conforme já elucidamos. Além disso, Freud ratifica a tese de que todas as pulsões têm uma natureza conservadora, pois "aspiram a restabelecer um estado perturbado pela gênese da vida" (1923, $A E$, p. 41; $S A$, p. 307). Apesar dessa natureza geral das pulsões, e esse é o terceiro aspecto, a pulsão de vida e de morte têm metas distintas. Enquanto a pulsão de morte encarrega-se de reconduzir o ser inorgânico ao estado inerte, a pulsão de vida tem como meta a síntese da substância viva dispersa em partículas, justamente para conservá-la (1923, $A E$, p. 41; $S A$, p. 307). Um quarto aspecto também essencial é reafirmado por Freud, baseado na tese do fisiologista Ewald Hering, citada em Além do princípio do prazer. As duas classes de pulsões coordenam-se com processos fisiológicos particulares em cada fragmento de ser vivo - o anabolismo e o catabolismo (1923, $A E$, p. $42 ; S A$, p. 308).

Além desses pontos inteiramente ratificados por Freud, ele introduz em $O$ eu e o isso pelo menos três esclarecimentos em relação ao Além do princípio do prazer. O primeiro deles consiste na afirmação de que as pulsões de vida e de morte se mesclam - por exemplo, através dos componentes sádicos da pulsão sexual - ou se separam - quando o sadismo se torna perversão, ainda que a separação não tenha sido levada ao extremo (1923, $A E$, p. $42 ; S A$, p. 308 ). A vida consistiria em um compromisso (Kompromiß) entre as duas aspirações, de conservação da vida e de retorno ao inorgânico (1923, $A E$, p. 42; $S A$, p. 307). Embora esse aspecto já pudesse ser deduzido das especulações de Além do princípio do prazer, agora a questão resta esclarecida. Essa explicação nos ajuda a compreender que se 
trata, em cada caso, de identificar o quanto a energia se transporta das excitações eróticas aos movimentos hostis e vice-versa. Enquanto a atitude hostil não tem perspectivas de satisfação, a atitude de amor oferece melhores possibilidades de descarga (1923, $A E$, p. 45; $S A$, p. 310-311). As pulsões eróticas parecem a Freud "mais plásticas, desviáveis e deslocáveis" (plastischer, ablenkbarer und verschiebbarer) que as pulsões de destruição, de modo que elas trabalham a serviço do princípio de prazer, "a fim de evitar congestionamentos facilitar as descargas" (um Stauungen zu vermeiden und Abfuhren $z u$ erleichtern). (1923, $A E$, p. 45; $S A$, p. 311). Inclusive, Freud faz alusão à similitude entre o estado de satisfação sexual plena e a morte (1923, $A E$, p. 48; $S A$, p. 314). Essa metáfora, ademais, é bastante comum em francês, por conta da expressão idiomática "la petite mort".

O segundo aspecto será determinante para a abordagem definitiva da pulsão de morte. Freud reingressa no campo da hipótese biológica na tentativa de especificar o modo como a pulsão de morte se exterioriza. Freud afirma que, como consequência da união dos organismos elementares unicelulares em seres vivos pluricelulares, neutralizou-se a pulsão de morte das células singulares, desviando-a para o mundo exterior através do órgão da musculatura, por seus movimentos destrutivos (destruktiven Regungen). É dessa forma que as pulsões de morte se exteriorizariam - ao menos parcialmente - como pulsão de destruição (Destruktionstrieb), dirigida ao mundo exterior e outros seres vivos (1923, $A E$, p. 42; $S A$, p. 308).

Um terceiro aspecto que merece a nossa atenção é mencionado no capítulo cinco As vassalagens do eu. A introdução da instância do "supereu" no campo da compreensão dinâmica dos mecanismos de introjeção, regulação e recalcamento levou Freud a outra inovação. O "supereu” tem independência do "eu” consciente e possui íntimos vínculos com o inconsciente (1923, $A E$, p. 53; $S A$, p. 319). Através desse vínculo, o "supereu” é capaz de se apoderar, através do sentimento de culpa, de todo sadismo disponível no indivíduo, voltando-se destrutivamente contra si. "O que agora governa o supereu é como um cultivo puro da pulsão de morte, que frequentemente logra efetivamente empurrar o eu até a morte (...)" (1923, $A E$, p. 54; $S A$, p. 319-320). Abre-se assim como um novo capítulo de abordagem para a psicanálise, no qual os movimentos destrutivos e autodestrutivos podem ser identificados como um resultado da ação do supereu, em sua captura da pulsão de morte.

Os três aspectos que apresentamos mostram suficientemente que Freud procurou aperfeiçoar a sua teoria do dualismo pulsional com o acabamento da segunda tópica. A interrogação que agora estamos em condições de fazer é: por que Freud enfatizou o caráter destrutivo relacionado à pulsão de morte, ao invés de simplesmente reiterar os conteúdos já explorados em Além do princípio do prazer? Uma reposta plausível a esta pergunta é que ele mesmo não estava satisfeito com a sua teoria sobre a compulsão à repetição e o traumático. A hesitação de Freud - como vimos, claramente manifesta em Além do 
Princípio do Prazer - reaparece em $O$ eu e o isso. Em nossa interpretação, não se trata de um mero acaso.

No tocante ao princípio do prazer, Freud afirma que não há dúvida alguma, pois apoia-se em justificação clínica. Ao contrário disso, "a distinção entre as duas classes de pulsões não parece suficientemente certificada e é possível que fatos da análise clínica invalidem a sua reinvindicação" (und möglicherweise heben Tatsachen der klinischen Analyse ihren Anspruch auf). (1923, AE, p. 43; SA, p. 309). Diante de tamanha hesitação, era preciso percorrer o caminho de uma explicação. E esse caminho se desenrola até a necessidade “de elaboração (Ausgestaltung) da doutrina do narcisismo”. (1923, AE, p. 47; $S A$, p. 312). Justamente ao dar este passo, quando Freud retoma a questão do narcisismo em sua explicação, ele hesita mais uma vez. Frequentemente fazemos a experiência de que as excitações pulsionais se revelam como originadas no Eros. "Se não fosse pelas considerações desenvolvidas em Mais além do princípio do prazer e, ultimamente, pelas contribuições sádicas ao Eros, nos resultaria difícil manter a intuição básica dualista” (1923, $A E$, p. 47; $S A$, p. 313). Porém, como Freud se vê forçado a manter o dualismo pulsional (Da wir aber dazu genötigt sind), impõe-se a impressão de que as pulsões de morte são mudas (stumm) e quase todo o barulho (Lärm) da vida parte do Eros (1923, $A E$, p. 47; $S A$, p. 313).

Não podemos diminuir a importância destas palavras. Não se trata de uma condescendência com o leitor. Freud realmente não parecia totalmente convencido de sua própria teoria e atribuía a ela um caráter hipotético, fruto da "especulação” (Spekulation) ou "intuição" (Anschaaung). Ora, ao fim e ao cabo, é necessário interrogar-se: se o trauma está na origem da compulsão à repetição e na fixação ao traumático, não se trataria pura e simplesmente de um incidente vital que alteraria o curso do princípio do prazer? Freud sabia que uma resposta satisfatória a essa interrogação, capaz de sustentar o dualismo pulsional, dependia da afirmação não apenas do caráter originário da pulsão de morte, mas especialmente, também, de sua autonomia. Caso não fosse demonstrada a autonomia da pulsão de morte, pelo fato de que ela se expressa sempre junto à pulsão de vida, seria bastante difícil argumentar em favor do dualismo pulsional. Isso porque poderíamos objetar que, no fundo, tudo não passa de uma só pulsão vital, com distintas expressões.

\section{(b) A inclinação agressiva como disposição pulsional autônoma}

Freud não parecia ainda totalmente satisfeito. Conforme sublinha Garcia-Roza, é somente em o Mal-estar na Cultura que Freud vai afirmar a absoluta autonomia da pulsão de morte $^{33}$. Essa afirmação é decisiva para a configuração final da pulsão de morte na obra

\footnotetext{
${ }^{33}$ ROZA, Introdução à Metapsicologia Freudiana. Volume 3, p. 158
} 
freudiana, que nós passaremos a analisar a partir de dois textos: Mal-estar na Cultura e a Conferência 32 - Angústia e vida pulsional.

O Mal-estar na Cultura é dos textos psicanalíticos sociais mais importantes de Freud, dividido em oito capítulos, cujo eixo central é o antagonismo entre as exigências pulsionais e as restrições culturais. O que nos interessa, fundamentalmente, se situa no desenvolvimento do sexto capítulo, onde Freud recapitula sua divergência com o monismo pulsional junguiano e retoma a sua teoria do dualismo pulsional (1930, $A E$, p. 114; $S A$, p. 246). Mais uma vez, Freud reafirma a sua tese sobre a compulsão à repetição e o caráter conservador da vida pulsional (1930, $A E$, p. 114; $S A$, p. 246). Partindo de especulações (Spekulationen) sobre o começo da vida e de paralelos biológicos, Freud extraiu a conclusão de que "além da pulsão para conservar a vida e reuni-la em unidades cada vez maiores, devia haver outra pulsão, oposta a ela, que dissolve essas unidades e as reconduz ao estado inorgânico inicial" (1930, $A E$, pp. 114-115; $S A$, p. 246). Os fenômenos da vida poderiam ser explicados por uma ação eficaz conjugada e contraposta de ambas as pulsões.

Freud faz referência às hesitações sobre a pulsão de morte no movimento psicanalítico. "A hipótese (Annhame) da pulsão de morte ou de destruição encontrou resistência mesmo dentro de círculos analíticos”. (1930, $A E$, p. 115; $S A$, p. 247). No começo, a concepção da pulsão de morte foi apenas uma tentativa desenvolvida, mas no decurso do tempo ela adquiriu um poder sobre Freud diante do qual ele não poderia mais pensar de outro modo (1930, $A E$, p. 115; $S A$, p. 247).

Por que razão a teoria da pulsão de morte adquiriu "um poder" sobre Freud? O que ele aporta propriamente de novo em Mal-estar na Cultura no tocante à pulsão de morte? Até então, ele havia reconhecido no sadismo e do masoquismo exteriorizações da pulsão de morte, embora fortemente articuladas ao erotismo. Em Mal-estar na Cultura, ele dá um passo mais: não podemos negligenciar a "ubiquidade” (Ubiquität) da agressão e destruição não eróticas (1930, $A E$, p. 116; $S A$, p. 247). Ele mesmo afirma recordar-se de sua atitude defensiva quando emergiu na bibliografia psicanalítica a ideia de pulsão de destruição $(1930, A E \text {, p. } 116 ; S A \text {, p. } 247)^{34}$. O que está em jogo e parece ser decisivo são as formas de

\footnotetext{
${ }^{34}$ Assinalamos duas passagens importantes da obra freudiana em que o tema da "pulsão de destruição" aparece, antes de sua consolidação no campo do dualismo pulsional instaurado por Além do princípio do prazer. O primeiro exemplo pode ser encontrado, sob a perspectiva da pulsão de dominação (Bemächtigungstrieb) nos Três ensaios sobre sexualidade, quando Freud trata da pulsão de dominação na masturbação masculina (1905, $A E$, p. 171, $S A$, p. 95); da crueldade advinda da pulsão de dominação que emerge na vida sexual antes do desenvolvimento dos genitais (1905, $A E$, p. 175; $S A$, p. 98); ou da pulsão de saber como uma forma sublimada da dominação (1905, $A E$, p. 176; SA, p. 100). Ainda nos Três ensaios sobre sexualidade, podemos encontrar uma menção à "pulsão para a crueldade" (Trieb zur Graumsamkeit), por exemplo, na relação entre a perversão e a crueldade (1905, $A E$, p. 151; $S A$, p. 75) ou no âmbito das fontes da sexualidade infantil (1905, AE, p. 151, $S A, 106)$. Em outro importante momento de sua obra, em sua análise do Pequeno Hans - Análise da fobia de um menino de cinco anos, Freud menciona a ideia de uma "pulsão de agressão" (Agressionstrieb) empregada por Adler, a partir de um cruzamento pulsional (Triebverschränkung)
} 
agressão, destruição e crueldade (Grausamkeit), as quais parecem se manifestar de modo desligado de um conteúdo erótico e como tal não podem ser ignoradas.

Freud reconhece mais uma vez o caráter eminentemente teórico da hipótese da pulsão de morte, de tal sorte que "é preciso admitir que não se encontra totalmente garantida contra objeções teóricas” (1930, $A E$, p. 117; $S A$, p. 249). Segundo suas palavras, é a investigação futura que aportará a claridade decisiva a essa questão. Encoraja-se então a afirmar - de modo inovador em sua obra - a autonomia da pulsão de morte. "Então, para tudo o que segue, situo-me nesse ponto de vista: a inclinação agressiva é uma disposição pulsional autônoma [selbständige], originária, do ser humano" (1930, $A E$, p. 117; $S A$, p. 249). Essa é a afirmação final de Freud para assentar a tese de que a cultura (Kultur) encontraria na pulsão de morte o seu obstáculo mais poderoso.

Praticamente três anos depois da publicação do Mal-estar na Cultura, Freud retorna uma vez mais ao tema da pulsão de morte, na Conferência 32 - Angústia e vida pulsional. “A doutrina das pulsões é nossa mitologia" (1933, $A E$, p. 88; $S A$, p. 529): não se pode prescindir dela, assim como não se pode vê-la com clareza. A interrogação freudiana nesta ocasião volta-se para o campo da autodestruição: “Em que contribuirá o traço conservador das pulsões para entender nossa autodestruição?” (1933, $A E$, p. 99; SA, p. 540). A autodestruição pode ser concebida como a expressão da pulsão de morte, que não está ausente em nenhum processo vital. "Da ação eficaz conjugada e contrária de ambas surgem os fenômenos da vida, a que a morte põe término”. (1933, $A E$, p. 99; $S A$, p. 540). E mais uma vez Freud expõe a necessidade de investigar como ambas as pulsões se mesclam no processo vital, de modo que a pulsão de morte seja colocada ao serviço de Eros, sobretudo em sua volta para fora na qualidade de agressão, "eis aí uma das tarefas reservadas à investigação futura”. (1933, $A E$, p. 100; $S A$, p. 540).

O que podemos perceber, portanto, é que no livro Mal-estar na Cultura e na Conferência 32 Freud apresenta sua derradeira hipótese da pulsão de morte, a qual se expressa como pulsão de dominação, pulsão agressiva, pulsão para a crueldade ou pulsão destrutiva, cuja natureza é autônoma em relação à pulsão de vida, embora se apresente, com frequência, mesclada com esta.

\section{Uma ponderação sobre a autonomia da pulsão de morte}

Propomos, por último, um balanço sobre esse aspecto derradeiro do dualismo pulsional em Freud que é a afirmação da agressividade como disposição pulsional autônoma. O que o texto indica é a notável inclinação de Freud, durante os anos 1930, para

- com algumas reservas. Em nota de rodapé, adicionada ulteriormente, ele procura enfatizar que ainda não havia estabelecido a teoria da pulsão de morte, a qual, de todo modo, seria distinta da teoria adleriana (1909, $A E$, p. $112, S A$, p. 117). 
afirmar a autonomia da pulsão de morte e, assim, assentar o dualismo pulsional. No entanto, queremos insistir um pouco mais sobre esse ponto, uma vez que Freud não ofereceu nenhum exemplo, nem mesmo em Mal-estar na Cultura, que demonstrasse a total autonomia da pulsão de morte, ou seja, aquilo que seria a "pura” agressão ou destruição sem nenhum componente libidinal.

Esse parece ter sido o grande problema de Freud, talvez a nervura de sua constante hesitação desde a concepção da teoria da pulsão de morte em 1920. Todos os exemplos apresentados - no enorme leque das diferentes formas de compulsão à repetição, incluindo o traumático, as neuroses de transferência, além das relações sadomasoquistas e das perversões, do infamiliar e da denegação - não apresentaram, de fato, uma pulsão de morte autônoma ou isolada. Freud chegou a afirmar, como vimos, a "natureza autônoma e originária da pulsão de morte" em Mal-estar na Cultura, mas não apresentou nesta ocasião qualquer exemplo clínico que fundamentasse a sua perspectiva.

Faremos um exercício ponderativo sobre a autonomia da pulsão de morte no interior da Segunda Tópica freudiana. Para tanto, iniciamos com uma reflexão sobre a diferença entre pulsão de morte e a pulsão de destruição. No Dicionário de Psicanálise de Laplanche e Pontalis, encontramos no verbete "pulsão de morte" uma importante anotação sobre a sua natureza: "As pulsões de morte dirigem-se primeiramente ao interior e tendem à autodestruição; secundariamente dirigir-se-iam para o exterior, manifestando-se então em forma de pulsão agressiva ou destrutiva” ${ }^{35}$. Como já tivemos a oportunidade de notar, Freud referiu-se à agressividade, à crueldade, ao sadismo e à destrutividade como formas de “expressão” da pulsão de morte.

A distinção entre a natureza primária e a secundária da pulsão de morte ajuda-nos a compreender por que a pulsão de morte originária, pulsão desligada, opera por descarga com a meta da eliminação completa da tensão - ou seja, retorno ao inorgânico - enquanto a sua exteriorização, na forma de pulsão agressiva ou autodestrutiva consistiria em sua expressão, ou natureza secundária. Com efeito, Freud parecia corroborar a distinção oferecida por Laplanche e Pontalis, uma vez mais que ele afirma no livro Mal-estar na Cultura a autonomia das pulsões agressivas, ou seja, da forma expressa da pulsão de morte. No entanto, mesmo seguindo esta definição, considerando todos os exemplos dados por Freud que analisamos nesse artigo, a natureza primária da pulsão de morte parece, de alguma forma, ainda reportada à dimensão libidinal, pois seria impossível promover a autodestruição sem atravessar o campo sensório-motor. Embora instrutiva, essa classificação não permite responder ao problema da autonomia da pulsão de morte, pois somente conseguimos observar a sua natureza secundária, quando ela se expressa conjuntamente com a pulsão de vida.

${ }^{35}$ LAPLANCHE, PONTALIS, Diccionário de psicoanálisis, p. 336 
Pelo fato de a autonomia da pulsão de morte ter sido defendida por Freud na última fase do seu pensamento, depois da Segunda Tópica, de 1930 a 1938, é comum, no âmbito institucional e clínico, que esta ideia seja afirmada e ensinada como um elemento característico de uma versão final da teoria psicanalítica. Colocaremos em relevo as interpretações oferecidas por dois importantes psicanalistas brasileiros que se detiveram sobre essa questão, Luiz Alfredo Garcia-Roza e Ignácio Paim Filho ${ }^{36}$.

Luiz Alfredo Garcia-Roza é o autor dos três volumes de Introdução à metapsicologia freudiana, já consagrada nos últimos anos. No terceiro volume de sua obra, destinado aos artigos de metapsicologia, Garcia-Roza apresenta certos desdobramentos do conceito de pulsão em psicanálise, introduzindo um desenvolvimento sobre a pulsão de morte, em consonância com o ensino de Lacan. O Mal-estar na Cultura oferece uma resposta sobre a autonomia das pulsões agressivas, mas Garcia-Roza percebe que a afirmação desta autonomia constitui uma ameaça ao próprio dualismo pulsional, "sem que Freud se dê conta disso" ${ }^{37}$. A pulsão de morte é invisível e silenciosa, está para além da representação e da palavra, portanto, fora do aparato psíquico e de suas determinações. Para Garcia-Roza, “além do princípio do prazer" seria sinônimo de "além do próprio aparato psíquico"38. Esse aspecto seria condizente com a ideia de que a pulsão de destruição, enquanto expressão da pulsão de morte, situa-se além da representação e da ordem e é pura dispersão, pura potência dispersa. Ora, se isso é verdade, então teríamos um problema ainda maior: "como situar, agora, as pulsões de vida?"39.

Para Garcia-Roza, uma diferenciação entre pulsão de morte e de vida que fosse anterior ao aparato psíquico careceria de sentido qualitativo, pois antes do aparato psíquico há o indiferenciado da pulsão. Qualquer determinação (e limitação) ao indeterminado das pulsões somente poderia vir de fora, ou seja, que não o próprio corpo pulsional - "esse outro lugar é o aparato psíquico, a rede de significantes que ordena o caos das pulsões” ${ }^{40}$. O sexual seria, dessa forma, a determinação que a pulsão vai receber e não

\footnotetext{
${ }^{36}$ O tema do dualismo pulsional é um campo de disputas interpretativas na psicanálise. Muitos autores apresentaram estudos relevantes sobre esse problema no Brasil, como, por exemplo, Luiz Roberto Monzani e Oswaldo Giacoia Jr. Monzani (Freud: o movimento de um pensamento) oferece diversos esclarecimentos sobre como a teoria das pulsões da segunda tópica seria muito mais uma revisão de aspectos que já haviam sido elaborados anteriormente por Freud, tais como a agressividade e a compulsão à repetição. Por sua vez, Giacoia (Ontologia e metapsicologia), enfatiza que a teoria da pulsão de morte respondeu ao risco representado pela exploração especulativa do conceito de narcisismo no tocante ao dualismo pulsional com o qual opera a metapsicologia freudiana. Optamos por Garcia-Roza e Paim Filho (Metapsicologia) por razões de delimitação, considerando que as suas leituras constituem uma boa ilustração do conflito das interpretações sobre a possibilidade de fundamentação da autonomia da pulsão de morte.

${ }^{37}$ ROZA, Introdução à Metapsicologia Freudiana. Volume 3, p. 159

${ }^{38}$ ROZA, Introdução à Metapsicologia Freudiana. Volume 3, p. 159

${ }^{39}$ ROZA, Introdução à Metapsicologia Freudiana. Volume 3, p. 159

${ }^{40}$ ROZA, Introdução à Metapsicologia Freudiana. Volume 3, p. 160
} 
um atributo da pulsão ela mesma. A pulsão, enquanto potência, é vazia de forma. Quando distinguimos tipos de pulsões, apontamos a diversidade das fontes e não uma diferença qualitativa $^{41}$.

Garcia-Roza percebe que essa interpretação tem duas consequências. A primeira seria a ameaça ao dualismo pulsional e a segunda, uma "capitis diminutio" da sexualidade. Para ele, o risco da segunda consequência parece menor - pois a interpretação mencionada em nada afeta a importância da sexualidade em psicanálise. "Ao contrário, a questão ganha maior especificidade e a sexualidade ficaria liberta de uma referência biológica incômoda e difícil de ser sustentada teoricamente" ${ }^{42}$. A primeira consequência - de uma ameaça ao dualismo pulsional -, esta sim parece a ele ter uma importância maior. Para afastar essa ameaça, ele desloca o ponto onde Freud faz incidir o dualismo: "A solução estaria em concebermos o dualismo pulsional não como um dualismo de natureza das pulsões, mas como um dualismo de modos da pulsão"43. Segundo a sua interpretação, o próprio Freud sugeriu que as pulsões, em si mesmas, seriam qualitativamente da mesma índole, uma vez que todas obedecem ao princípio da redução das tensões. A sua diferença estaria na sua apresentação, nos seus modos disjuntivo e conjuntivo ${ }^{44}$ - o que vimos no exame do texto $A$ denegação.

Até esse ponto, a abordagem de Garcia-Roza mostra-se esclarecedora e, ademais, coerente com o pensamento de Freud. Entretanto, no parágrafo seguinte, ele parece querer introduzir uma nova elaboração do dualismo pulsional que diverge - e inverte - o pensamento freudiano. Garcia-Roza parte da afirmação freudiana segundo a qual, na cultura, os indivíduos reúnem-se em totalidades cada vez mais abrangentes, até a humanidade. Acrescenta, porém, que, da singularidade individual à totalidade humana teríamos uma crescente indiferenciação. "Se entendermos o desejo como pura diferença, o projeto de Eros seria o da eliminação das diferenças e, portanto, do desejo, num indiferenciação final que é a humanidade" ${ }^{45}$. E ele vai além disso: “A pulsão de morte enquanto potência destrutiva (ou princípio disjuntivo) é o que impede a repetição do 'mesmo', isto é, a permanência das totalidades constituídas, provocando a emergência de novas formas" ${ }^{46}$. A discordância total e completa para com Freud - e mesmo para com todo raciocínio realizado até então - não é mera aparência ${ }^{47}$.

\footnotetext{
${ }^{41}$ ROZA, Introdução à Metapsicologia Freudiana. Volume 3, p. 160

${ }^{42}$ ROZA, Introdução à Metapsicologia Freudiana. Volume 3, p. 162

${ }^{43}$ ROZA, Introdução à Metapsicologia Freudiana. Volume 3, p. 162, grifo original

${ }^{44}$ ROZA, Introdução à Metapsicologia Freudiana. Volume 3, p. 162

${ }^{45}$ ROZA, Introdução à Metapsicologia Freudiana. Volume 3, p. 163

${ }^{46}$ ROZA, Introdução à Metapsicologia Freudiana. Volume 3, p. 163

47 Vejamos ainda este trecho: "Neste sentido, contrariamente à ideia de pulsão de morte como retorno às formas anteriores, temos a pulsão de morte concebida como potência criadora, posto que impõe novos começos ao invés de reproduzir o mesmo. A função conservadora estaria do lado de Eros, enquanto a pulsão
} 
Depois de uma afirmação tão paradoxal relativamente a tudo o que foi sustentado, Garcia-Roza não oferece maiores explicações, além de uma nota de rodapé na qual promete um novo volume sobre a pulsão de morte (e que lamentavelmente terminou não escrevendo). Trata-se não mais da afirmação, mas da inversão do dualismo pulsional em Freud, embora não passe do terreno alusivo. A pulsão de morte não seria conservadora, apenas a de vida. E de outro lado, a compulsão à repetição seria decorrente da pulsão de vida, não da pulsão de morte, a qual seria a verdadeira pulsão "criadora”. Ao que parece, a intenção de apostar na força "criativa” da pulsão de morte levou Garcia-Roza a uma elucubração que carece de argumentos.

Não obstante, a alternativa de conceber o dualismo pulsional como um dualismo de modos e não de natureza, proposta por Garcia-Roza, parece-nos bastante instrutiva. Dessa construção não decorre logicamente o inesperado passo dado por ele nos parágrafos seguintes - que claramente inverte o dualismo pulsional freudiano. Porém, ainda que utilizemos a sua proposta para definir as pulsões em sua diferenciação de modos, em nada ela nos ajuda a exemplificar a autonomia das inclinações agressivas.

Seguimos na busca de uma solução. Ignácio Paim Filho, em seu livro Metapsicologia: Um olhar à luz da pulsão de morte, opta por manter o dualismo tal como concebido por Freud, oferecendo exemplos que auxiliam a compreender a teoria da pulsão de morte no campo clínico. Há, entre todos os capítulos, especialmente um no qual ele visa apresentar um novo paradigma do "representável e do irrepresentável" para pensar as estruturas clínicas $^{48}$. Paim Filho vem ao socorro da teoria da pulsão de morte freudiana e examina, nas diversas estruturas patológicas, aquilo que seria o modo de incidência da pulsão de morte. Ao longo da sua argumentação, ele afirma que "a angústia, enquanto força desligada, representa a forma mais fidedigna de apresentação da pulsão de morte desgarrada" ${ }^{49}$. Com efeito, a angústia da qual fala Ignácio não se produz nem se mantém como relação objetal, o que reclamaria, por si só, a passagem ao sensível e, portanto, as excitações de ordem libidinal, misturando-se ao campo do prazer. Ele trata, ao contrário, da ausência de representabilidade, do vazio e do silêncio, de uma energia livre que se expressa na forma da angústia de separação e intrusão ${ }^{50}$.

Ora, concebendo a dinâmica da pulsão de morte desde a sua natureza desligada - e, portanto, irrepresentável, mais além do princípio do prazer - Paim Filho oferece uma solução que não nos distancia de Freud e, ao mesmo tempo, dá sinais de responder à pergunta que formulamos. A angústia caracteriza a forma mais fidedigna de apresentação da pulsão de morte desgarrada, ou seja, desligada e perceptível em sua autonomia. Paim

de morte seria a produtora de novos começos, verdadeira potência criadora”. (Garcia-Roza, Introdução à Metapsicologia Freudiana. Volume 3, p. 163).

${ }^{48}$ PAIM FILHO, Metapsicologia, p. 161 - 178

${ }^{49}$ PAIM FILHO, Metapsicologia, p. 174

${ }^{50}$ PAIM FILHO, Metapsicologia, p. 174 
Filho situa sua abordagem no campo das estruturas patológicas, ou seja, não da angústia adaptativa, mas daquela que produz desadaptação e sofrimento, pois se trata de energia desligada e sem relação com qualquer dimensão objetal, portanto, sem representação e vazia. Daí a sua força, que por vezes chega a arrastar toda e qualquer potencial ligação com a dimensão libidinal. No regime do aparelho psíquico, a energia desligada que se desgarra e não se deixa simbolizar, sob a forma de angústia, esta sim, poderia evidenciar um campo onde a pulsão de morte se mostra na sua autonomia.

No entanto, insistimos com a nossa pergunta. Se a angústia constitui um exemplo para Freud - e o mais fidedigno - da pulsão de morte desgarrada, por que ele mesmo não afirmou isso? Ademais, é curioso que Freud não tenha realizado um aprofundamento sobre a relação entre angústia e a pulsão de morte em Inibição, sintoma e angústia $(1926)^{51}$, texto posterior à Além do princípio do prazer. Uma hipótese para isso é que Freud relacionava a angústia com a pulsão de vida, seja por caracterizar um aviso, um sinal, um alarme próprio à conservação -, seja por dizer respeito a um tipo de agitação que certamente não é característica da pulsão de morte, mesmo nos casos patológicos.

Quando Paim Filho se refere a exemplos clínicos ou observáveis ao longo do seu livro, a pulsão de morte aparece sempre relacionada, mesclada com a pulsão de vida. Mesmo a angústia, seja ela adaptativa ou desfuncional, expressa-se pela via corporal. A explicação metapsicológica sobre a angústia desadaptativa enquanto energia desligada, sem representação e dimensão objetal, não pode tornar-se um pretexto de evidência clínica sobre a autonomia da pulsão de morte, pois uma vez manifesta a angústia, necessariamente se interpõe a dimensão sensório-motora e já ocorre, em algum grau, a passagem pela dimensão libidinal. Tudo indica que a solução de Paim Filho, na esteira de Freud, permanece no campo teórico da metapsicologia, mas não é capaz de oferecer, assim como criador da psicanálise, um exemplo clínico da autonomia da pulsão de morte. A afirmação do dualismo pulsional e da autonomia da pulsão de morte permanecem como hipóteses sustentáveis exclusivamente no terreno da metapsicologia.

\section{Considerações finais}

O problema que constituiu o fio condutor dessa investigação foi a autonomia da pulsão de morte na metapsicologia freudiana. Tomamos por decisão metodológica selecionar os textos de Freud que permitem mostrar a evolução da teoria do dualismo pulsional (pulsão de vida e pulsão de morte) paralelamente à concepção da Segunda Tópica.

\footnotetext{
${ }^{51}$ Como sustentam Laplanche e Pontalis: "No artigo Inibição, sintoma e angústia (Hemmung, Symptom und Angst, 1926), que reconsidera o conjunto do conflito neurótico e suas diversas modalidades, surpreende efetivamente ver o pouco lugar que Freud concede à oposição entre os dois tipos de pulsões, oposição a que não atribui papel dinâmico algum” (Diccionário de psicoanálisis, p. 339).
} 
Nesse sentido, o primeiro texto analisado de forma sistemática foi Além do Princípio do Prazer, de 1920, que representa uma virada na teoria freudiana e inaugura uma nova forma de compreender a compulsão à repetição. Fizemos ainda o percurso de alguns textos, selecionando as passagens que dizem respeito à pulsão de morte, a fim de explorar os exemplos oferecidos por Freud em sua obra. Procuramos mostrar que a defesa de uma autonomia da pulsão de morte ocorre tardiamente, no texto Mal-estar na Cultura, de 1930. Chegamos ao impasse de que Freud não oferece nenhum exemplo sobre a pulsão de morte autônoma, nem mesmo nesse texto.

Por essa razão, recorremos aos comentadores Luiz Alfredo Garcia-Roza e Ignácio Paim Filho, com o objetivo de apresentar duas diferentes possibilidades de interpretação. A resposta oferecida por Ignácio Paim Filho pareceu-nos a mais adequada considerando a nossa decisão metodológica, neste artigo, de permanecermos restritos ao escopo teórico da produção freudiana. Porém, a afirmação de que a angústia é o melhor exemplo da pulsão de morte desgarrada, embora plausível no campo da teoria metapsicológica, não tem melhor sucesso do que os demais exemplos clínicos oferecidos por Freud, os quais sempre se apresentam misturados em algum grau com a pulsão de vida.

Se Freud não encontrou nenhum exemplo claro de inclinação agressiva ou destrutiva autônoma, talvez seja porque, no campo da sua exteriorização, a pulsão de morte esteja sempre - em algum grau, maior ou menor - relacionada à pulsão de vida. Ademais, é o que ele admitiu em $O$ eu e o isso. Não resta dúvida sobre o princípio do prazer em razão de sua justificação clínica, enquanto a distinção entre as duas classes de pulsões não parecia lhe certificada (Freud, 1923, $A E$, p. 43; $S A$, p. 309). Esperamos ter mostrado que Freud não encontrou uma solução adequada para o problema da autonomia da pulsão de morte, pois na ausência da demonstração clínica ou observável, restou-lhe apenas o terreno da metapsicologia para sustentar a sua hipótese.

Reconhecemos que esse tema foi alvo das mais variadas disputas e polêmicas na história da psicanálise. Muitos autores chegaram a negar ou considerar inócua a hipótese da pulsão de morte. Importantes psicanalistas como Winnicott, por exemplo, tornaram-se fervorosos críticos ao modelo freudiano da teoria das pulsões ${ }^{52}$. Uma análise sobre o debate travado entre os mais importantes teóricos do movimento psicanalítico acerca da pulsão de morte fica em aberto para novas investigações possíveis.

\section{Referências}

\section{Obras de Sigmund Freud}

“Obras Completas”, Amorrortu Editores (espanhol)

${ }^{52}$ Cf. LOPARIC, De Freud a Winnicott: aspectos de uma mudança paradigmática 
FREUD, Sigmund (1892). Carta a Josef Breuer - 29.6.92. Obras completas. Vol. I. 2-a ed. Trad. José Luis Etcheverry. Buenos Aires: Amorrortu, 2013, pp. 183-184.

FREUD, Sigmund (1895). Proyecto de psicología. Obras completas. Vol. I. 2ª ed. Trad. José Luis Etcheverry. Buenos Aires: Amorrortu, 2013, pp. 339-436.

FREUD, Sigmund (1900). La interpretación de los sueños (segunda parte). Obras completas. Vol. V. $2^{\mathrm{a}}$ ed. Trad. José Luis Etcheverry. Buenos Aires: Amorrortu, 2014, pp. 345-611.

FREUD, Sigmund (1905). Tres ensayos de teoría sexual. Obras completas. Vol. VII. 2a ed. Trad. José Luis Etcheverry. Buenos Aires: Amorrortu, 2013, pp. 123-223.

FREUD, Sigmund (1909). Análisis de la fobia de un niño de cinco años. Obras completas. Vol. VII. 2 ${ }^{\mathrm{a}}$ ed. Trad. José Luis Etcheverry. Buenos Aires: Amorrortu, 2013, pp. 7-118.

FREUD, Sigmund (1914). Recordar, repetir y reelaborar (Nuevos consejos sobre la técnica del psicoanálisis, II). Obras completas. Vol. XII. 2aㅡ. ed. Trad. José Luis Etcheverry. Buenos Aires: Amorrortu, 2012, pp. 149-157.

FREUD, Sigmund (1915). Lo inconsciente. Obras completas. Vol. XIV. 2aㅡ ed. Trad. José Luis Etcheverry. Buenos Aires: Amorrortu, 2012, pp. 153-214.

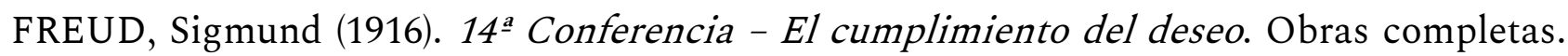
Vol. XV. 2 ${ }^{\mathbf{a}}$ ed. Trad. José Luis Etcheverry. Buenos Aires: Amorrortu, 2012, pp. 11-220.

FREUD, Sigmund (1918). De la historia de uma neurosis infantil (el "Hombre de los Lobos"). Obras completas. Vol. XVII. 2 ${ }^{\mathbf{a}}$ ed. Trad. José Luis Etcheverry. Buenos Aires: Amorrortu, 2013, pp. 9-112.

FREUD, Sigmund (1919a). Lo ominoso. Obras completas. Vol. XVII. 2ª ed. Trad. José Luis Etcheverry. Buenos Aires: Amorrortu, 2013, pp. 219-251.

FREUD, Sigmund (1919b). Introducción a Zur Psychoanalyse der Kriegsneurosen. Obras completas. Vol. XVII. 2 ed. Trad. José Luis Etcheverry. Buenos Aires: Amorrortu, 2013, pp. 205-208.

FREUD, Sigmund (1920). Mas allá del principio de placer. Obras completas. Vol. XVIII. 2ª ed. Trad. José Luis Etcheverry. Buenos Aires: Amorrortu, 2013, pp. 07-63.

FREUD, Sigmund (1923). El yo y el ello. Obras completas. Vol. XIX. 2ª ed. Trad. José Luis Etcheverry. Buenos Aires: Amorrortu, 2013, pp. 15-66.

FREUD, Sigmund (1924). El problema económico del masoquismo. Obras completas. Vol. XIX. 2a ed. Trad. José Luis Etcheverry. Buenos Aires: Amorrortu, 2013, pp. 165-176.

FREUD, Sigmund (1925). La negación. Obras completas. Vol. XIX. 2 $2^{\mathbf{a}}$ ed. Trad. José Luis Etcheverry. Buenos Aires: Amorrortu, 2013, pp. 253-257. 
98 | A autonomia da pulsão de morte na metapsicologia freudiana

FREUD, Sigmund (1926). Inhibición, sintoma y angustia. Obras completas. Vol. XX. 2ª ed. Trad. José Luis Etcheverry. Buenos Aires: Amorrortu, 2013, pp. 83-163.

FREUD, Sigmund (1927). El humor. Obras completas. Vol. XXI. 2ª ed. Trad. José Luis Etcheverry. Buenos Aires: Amorrortu, 2012, pp. 157-162.

FREUD, Sigmund (1930). El malestar en la cultura. Obras completas. Vol. XXI. 2ª ed. Trad. José Luis Etcheverry. Buenos Aires: Amorrortu, 2012, pp. 65-140.

FREUD, Sigmund (1933). 32 $2^{a}$ conferencia. Angustia y vida pulsional. Obras completas. Vol. XXI. 2⿳a ed. Trad. José Luis Etcheverry. Buenos Aires: Amorrortu, 2013, pp. 75-103.

\section{“Studienausgabe”- Fischer Verlag (alemão)}

FREUD, Sigmund (1900). Die Traumdeutung. Studiensausgabe. Vol. III. Frankfurt am Main: Fischer, 1975, pp. 29-590.

FREUD, Sigmund (1905). Drei Abhanlungen zur Sexualtheorie. Studiensausgabe. Vol. III. Frankfurt am Main: Fischer, 1975, pp. 43-145.

FREUD, Sigmund (1909). Analyse der Phobie einer infantilen Neurose. Studiensausgabe. Vol. VIII. Frankfurt am Main: Fischer, 1975, pp. 13-123.

FREUD, Sigmund (1915). Das Unbewusste. Studiensausgabe. Vol. III. Frankfurt am Main: Fischer, 1975, pp. 125-173.

FREUD, Sigmund (1916). 14. Vorlesung - Die Wunscherfüllung. Studiensausgabe. Vol. I. Frankfurt am Main: Fischer, 1975, pp. 217-230.

FREUD, Sigmund (1918). Aus der Geschichte einer infantilen Neurose ["Der Wolfsmann"]. Studiensausgabe. Vol. VIII. Frankfurt am Main: Fischer, 1975, pp. 129-231.

FREUD, Sigmund (1919a). Das Unheimliche. Studiensausgabe. Vol. I. Frankfurt am Main: Fischer, 1975, pp. 243-274.

FREUD, Sigmund (1920). Jenseits des Lustprinzips. Studiensausgabe. Vol. III. Frankfurt am Main: Fischer, 1975, pp. 217-272.

FREUD, Sigmund (1923). Das Ich und das Es. Studiensausgabe. Vol. III. Frankfurt am Main: Fischer, 1975, pp. 283-330.

FREUD, Sigmund (1924). Das ökonomische Problem des Masochismus. Studiensausgabe. Vol. III. Frankfurt am Main: Fischer, 1975, pp. 343-354.

FREUD, Sigmund (1925). Die Verneinung. Studiensausgabe. Vol. III. Frankfurt am Main: Fischer, 1975, pp. 373-377. 
FREUD, Sigmund (1926). Hemmung, Symptom und Angst. Studiensausgabe. Vol. VI. Frankfurt am Main: Fischer, 1975, pp. 233-308.

FREUD, Sigmund (1927). Der Humor. Studiensausgabe. Vol. IV. Frankfurt am Main: Fischer, 1975, pp. 277-282.

FREUD, Sigmund (1930). Das Unbehagen in der Kultur. Studiensausgabe. Vol. IX. Frankfurt am Main: Fischer, 1975, pp. 197-270.

FREUD, Sigmund (1933). 32. Angst und Triebleben. Studiensausgabe. Vol. I. Frankfurt am Main: Fischer, 1975, pp. 517-543.

\section{Outras obras citadas}

FREUD, Sigmund (1986). A correspondência completa de Sigmund Freud para Wilhem Fliess (1897-1904). Editado por Jeffrey Moussaieff Masson, Trad. Vera Ribeiro. Rio de Janeiro: Imago.

FREUD, Sigmund (1998). Além do princípio do prazer. Trad. do inglês por Christiano Monteiro Oiticica. Rio de Janeiro: Imago.

FREUD, Sigmund (2019). O infamiliar [Das Unheimlich]. Seguido de O Homem de Areia. Ed. bilíngue. Trad. Ernani Chaves e Pedro Heliodoro Tavares. Rio de Janeiro: Autêntica.

FREUD, Sigmund; ABRAHAM, Karl (1979). Correspondencia (1907-1926). Trad. para o espanhol por Ramón Alcade. Barcelona: Gedisa.

FREUD, Sigmund; FREUD, Anna (2008). Correspondência (1904-1938). Trad. Kristinia Michahelles. Porto Alegre: L\&PM.

\section{Bibliografia geral}

ANDRADE, Fernando Cézar Bezerra de (2011). "A metapsicologia do masoquismo em Freud e Laplanche”. Estados de Psicanálise, n 36, pp. 55-68.

CROMBERG, Renata Udler (2014). (Org.). Sabina Spielrein - Uma pioneira da psicanálise. Obras completas, Vol. I. São Paulo: Livros da Matriz.

DERRIDA, Jacques (1980). La Carte Postale - de Socrate à Freud et au-delà. Paris : Flammarion.

MALABOU, Catherine (2007). Les Nouveaux Blessés. De Freud à la neurologie, penser les traumatismes contemporains. Paris : Bayard.

FECHNER, Gustav Theodor (1873). Einige Ideen zur Schöpfungs- und Entwickelungsgeschichte der Organismen. Leipzig: Breitkopf und Härtel. 
FECHNER, Gustav Theodor (1860). Elemente der Psychophysik - Erster Teil. Leipzig: Breitkopf und Härtel.

FERENCZI, Sándor (1994). "The problem of acceptance of unpleasant ideas-advances in knowledge of the sense of reality”. Further contributions to the Theory and Technique of Psycho-analysis. Londres: Karnac, pp. 366-379.

GARCIA-ROZA, Luiz Alfredo (1991). Introdução à Metapsicologia Freudiana. Volume 1 Sobre as afasias (1891), O projeto de 1895. Rio de Janeiro: Zahar.

GARCIA-ROZA, Luiz Alfredo (1995). Introdução à Metapsicologia Freudiana. Volume 3 Artigos de metapsicologia (1914-1917) - narcisismo, pulsão, recalque e inconsciente. Rio de Janeiro: Zahar.

GIACOIA JR., Oswaldo (2012). “Ontologia e metapsicologia: Considerações sobre o dualismo pulsional”. Ideias, no 4 (nova série), p. 123-143.

HYPPOLITE, Jean (1966). “Commentaire parle sur la Verneinung de Freud”. LACAN, Jacques. Écrits I. Paris: Seuil, pp. 527-537.

KLEIN, Melanie (1975). “On Observing the Behaviour of Young Infants”. Envie and gratitude and other works (1946-1963). Londres: The International Psycho-analytical Library, pp. 94-121.

LACAN, Jean (1966). “Réponse au Commentaire de Jean Hyppolite sur la 'Verneinung' de Freud”. LACAN, Jacques. Écrits I. Paris: Seuil, pp. 379-397.

LAPLANCHE, Jean; PONTALIS, Jean-Bertrand (2004). Diccionário de psicoanálisis. Dirigido por Daniel Lagache. Buenos Aires: Paidós.

LOPARIC, Zeljko (2006). "De Freud a Winnicott: aspectos de uma mudança paradigmática”. Winnicott e-prints, vol.1, no 1, pp. 1-29.

LOW, Barbara (2014). Psycho-analysis - A brief account on the Freudian theory. Nova Iorque: Routledge.

MONZANI, Luiz Roberto (2013). Freud: o movimento de um pensamento. Campinas: Editora da Unicamp.

PAIM FILHO, Ignácio Alves (2014). Metapsicologia: um olhar à luz da pulsão de morte. Porto Alegre: Movimento.

RAFFAELli, Rafael (1994). "Psicanálise e Percepção”. Revista de Ciências Humanas, Florianópolis, vol. 12, n 16, p. 77-104.

SCHUR, Max (1975). La mort dans la vie de Freud. Trad. do inglês por Brigitte Bost. Paris: Gallimard. 
SPIELREIN, Sabina (1994). "Destruction as the cause of coming into being". Journal of Analytical Psychology, n ${ }^{39}$, pp. 155-186.

STEIN, Ernildo (2000). "A desconstrução do eu: a Zerlegung de Freud e a Auslegung de Heidegger”. Diferença e Metafísica - Ensaios sobre a desconstrução. Porto Alegre: Edipucrs, pp. 170-192. 